\title{
MicroRNA expression profiling identifies decreased expression of miR-205 in inflammatory breast cancer
}

Lei Huo ${ }^{1,2}$, Yan Wang ${ }^{1}$, Yun Gong ${ }^{1,2}$, Savitri Krishnamurthy ${ }^{1,2}$, Jing Wang ${ }^{3}$, Lixia Diao ${ }^{3}$, Chang-Gong Liu ${ }^{4}$, Xiuping Liu ${ }^{4}$, Feng Lin ${ }^{1}$, William F Symmans ${ }^{1}$, Wei Wei ${ }^{5}$, Xinna Zhang ${ }^{6}$, Li Sun ${ }^{1}$, Ricardo H Alvarez ${ }^{2,7}$, Naoto T Ueno ${ }^{2,7}$, Tamer M Fouad ${ }^{7}$, Kenichi Harano ${ }^{7}$, Bisrat G Debeb ${ }^{2,8}$, Yun $\mathrm{Wu}^{1}$, James Reuben ${ }^{2,9}$, Massimo Cristofanilli ${ }^{10}$ and Zhuang Zuo ${ }^{9}$

${ }^{1}$ Department of Pathology, The University of Texas MD Anderson Cancer Center, Houston, TX, USA; ${ }^{2}$ Morgan Welch Inflammatory Breast Cancer Research Program and Clinic, The University of Texas MD Anderson Cancer Center, Houston, TX, USA; ${ }^{3}$ Department of Bioinformatics and Computational Biology, The University of Texas MD Anderson Cancer Center, Houston, TX, USA; ${ }^{4}$ Department of Experimental Therapeutics, The University of Texas MD Anderson Cancer Center, Houston, TX, USA; ${ }^{5}$ Department of Biostatistics, The University of Texas MD Anderson Cancer Center, Houston, TX, USA; ${ }^{6}$ Department of Gynecologic Oncology and Reproductive Medicine, The University of Texas MD Anderson Cancer Center, Houston, TX, USA; ${ }^{7}$ Department of Breast Medical Oncology, The University of Texas MD Anderson Cancer Center, Houston, TX, USA; ${ }^{8}$ Department of Experimental Radiation Oncology, The University of Texas MD Anderson Cancer Center, Houston, TX, USA; ${ }^{9}$ Department of Hematopathology, The University of Texas MD Anderson Cancer Center, Houston, TX, USA and ${ }^{10}$ Department of Hematology and Oncology, Northwestern University, Chicago, IL, USA

Inflammatory breast cancer is the most aggressive form of breast cancer. Identifying new biomarkers to be used as therapeutic targets is in urgent need. Messenger RNA expression profiling studies have indicated that inflammatory breast cancer is a transcriptionally heterogeneous disease, and specific molecular targets for inflammatory breast cancer have not been well established. We performed microRNA expression profiling in inflammatory breast cancer in comparison with locally advanced noninflammatory breast cancer in this study. Although many microRNAs were differentially expressed between normal breast tissue and tumor tissue, most of them did not show differential expression between inflammatory and noninflammatory tumor samples. However, by microarray analysis, quantitative reverse transcription PCR, and in situ hybridization, we showed that microRNA-205 expression was decreased not only in tumor compared with normal breast tissue, but also in inflammatory breast cancer compared with noninflammatory breast cancer. Lower expression of microRNA-205 correlated with worse distant metastasis-free survival and overall survival in our cohort. A small-scale immunohistochemistry analysis showed coexistence of decreased microRNA-205 expression and decreased E-cadherin expression in some ductal tumors. MicroRNA-205 may serve as a therapeutic target in advanced breast cancer including inflammatory breast cancer.

Modern Pathology (2016) 29, 330-346; doi:10.1038/modpathol.2016.38; published online 26 February 2016

Inflammatory breast cancer is the most aggressive form of breast cancer consisting of $1-5 \%$ of newly diagnosed breast cancer in the United States. ${ }^{1}$ It is

Correspondence: Dr L Huo, MD, PhD, Department of Pathology, The University of Texas MD Anderson Cancer Center, 1515 Holcombe Boulevard, Unit 85, Houston, TX 77030, USA.

E-mail: leihuo@mdanderson.org

Received 19 November 2015; revised 9 January 2016; accepted 9 January 2016; published online 26 February 2016 characterized by clinical hallmarks of diffuse erythema and edema (peau d'orange) involving one-third or more of the breast skin caused by tumor emboli blocking dermal lymphatics, and rapid progression from the onset of the disease. At the time of presentation, 55 to $85 \%$ of patients have regional lymph node metastasis clinically. ${ }^{2}$ Despite improved survival in the past three decades because of the introduction of multimodality treatment approaches, the survival outcomes of patients with 
inflammatory breast cancer remain poorer compared with patients with noninflammatory, locally advanced breast cancer, ${ }^{3,4}$ underscoring the need for understanding the biology of the disease and exploring new therapeutic targets.

Inflammatory breast cancer is known to be a heterogeneous disease histomorphologically, also reflected at the molecular level. The few published mRNA expression profiling studies to date have indicated that transcriptional heterogeneity exists in inflammatory breast cancer as extensively as in noninflammatory breast cancer, and that the established molecular subtypes such as luminal, HER2-positive, and basal-type can be identified in inflammatory breast cancer. ${ }^{5-16}$ Although some of the studies have demonstrated differences in mRNA expression levels between inflammatory breast cancer and noninflammatory breast cancer samples, a specific inflammatory breast cancer signature cannot be deduced from these studies.

One intrinsic limitation in mRNA expression profiling studies of inflammatory breast cancer lies in the combination of the rarity of the disease and poor preservation of mRNA in retrospectively collected formalin-fixed, paraffin-embedded tissue. To this end, recent studies have explored tumor profiling of microRNAs (miRNAs), small ( 22 nt), single-stranded nonprotein coding RNA molecules that suppress gene expression by binding to the $3^{\prime}$ untranslated regions of the target mRNAs. ${ }^{17}$ Because of their small size, miRNAs are highly stable in fresh frozen as well as formalin-fixed, paraffin-embedded tissue, providing a competitive advantage compared with standard transcriptome analysis with regard to the possibility to explore their potential roles as robust biomarkers in inflammatory breast cancer. More important than its feasibility, recent advances have implicated the role of miRNA as oncogenes or tumor suppressor genes in tumorigenesis, metastasis, and response to treatment in various cancer types including breast cancer. ${ }^{18-27}$ Although the number of miRNAs identified is relatively small ( $\sim 2588$ human mature miRNAs from 1881 precusor miRNA genes reported in miRBASEv.21; www.mirbase.org), individual miRNAs can target multiple genes, and it is thought that collectively they can target approximately onethird of the human genes. ${ }^{28}$ Thus, they act as global regulators and may be suitable diagnostic markers and therapeutic targets for inflammatory breast cancer.

In this study, the miRNA expression profiles of 23 inflammatory breast cancer, 24 noninflammatory breast cancer, and 12 normal breast tissue fresh frozen samples were generated using a previously validated miRNA microarray assay. ${ }^{29,30}$ The differentially expressed miRNA with the highest fold change, miR-205, was further investigated.

\section{Materials and methods}

\section{Human Breast Tumor Samples}

This study was approved by the institutional review board of MD Anderson Cancer Center. Fifty-three patients treated between 1997 and 2011 at MD Anderson Cancer Center with available fresh frozen breast tissue were identified from the institutional inflammatory breast cancer registry and institutional tissue bank, and included in the microarray study. Among these, 23 patients had the clinical diagnosis of inflammatory breast cancer with biopsy confirmed carcinoma in the underlying breast, and 24 had noninflammatory breast cancer that met the following criteria: clinically and/or pathologically, $\mathrm{T} 4$, or tumor $\geq 5 \mathrm{~cm}$, or $\mathrm{T} 2$ (tumor $\geq 3 \mathrm{~cm}$ ) N2. In addition, 12 samples of normal breast tissue, 6 from the above 47 patients and 6 from additional patients, were used in the microarray study as normal controls. Patient age, tumor histologic type, lymph node status, the status of lymphovascular invasion, prognostic/predictive marker status, clinical stage, pathologic stage, and history of neoadjuvant chemotherapy were retrospectively recorded from the medical records. In inflammatory breast cancer patients, because pathologic restaging does not occur after neoadjuvant chemotherapy, the pathologic stage was the same as the clinical stage, except when the ypN was higher than the pretreatment $\mathrm{N}$ stage, the $\mathrm{ypN}$ was used for pathologic stage. The American Society of Clinical Oncology (ASCO)/College of American Pathologists (CAP) guideline recommendations were used as references with minor modifications for scoring estrogen receptor, progesterone receptor, and HER2 ${ }^{31,32}$ that were performed as part of the routine pathology evaluation. Estrogen receptor and progesterone receptor status were determined by immunohistochemical staining. Positive staining was defined as nuclear staining in at least $5 \%$ of invasive cancer cells. HER2 status was tested by fluorescence in situ hybridization or by immunohistochemical staining. Triple-negative (estrogen receptor negative, progesterone receptor negative, and HER2 negative) was defined accordingly.

For in situ hybridization analysis, formalin-fixed, paraffin-embedded tissue from 23 of the above patients with available tissue and six additional inflammatory breast cancer patients treated at MD Anderson Cancer Center during the above-mentioned time period was obtained from the surgical pathology files in the Department of Pathology. The total of 29 cases included 5 pretreatment inflammatory breast cancer samples, 9 postchemotherapy inflammatory breast cancer samples, 8 pretreatment noninflammatory breast cancer samples, and 7 postchemotherapy non-inflammatory breast cancer samples. Two pretreatment noninflammatory breast cancer specimens were invasive lobular carcinoma and the remaining 27 specimens were invasive ductal carcinoma. 


\section{MicroRNA Microarray Analysis}

Total RNA, including miRNA, was extracted from frozen tissues by homogenization with TRI reagent (Life Technologies, Grand Island, NY, USA) according to the manufacturer's instructions. RNA quality and quantity were evaluated by NanoDrop Spectrophotometer (Nanodrop Technologies, Wilmington, DE, USA) and Agilent 2100 Bioanalyzer (Agilent Technologies, Santa Clara, CA, USA). The miRNA expression profiling on miRNA microarray was performed as previously described. ${ }^{29,30}$ Briefly, $3 \mu \mathrm{g}$ of total RNA from each sample was biotin labeled by reverse transcription using 5 '-end biotin-labeled random octomer oligo primer. Hybridization of biotin-labeled cDNA was carried out on a miRNA microarray chip (MD Anderson, Version 5.0) that contains 2100 miRNA probes, including 678 human and 472 mouse miRNA genes obtained from Sanger miRBase V12, in duplicate. Hybridization signals were detected by biotin binding of a streptavidin-Alexa647 conjugate by using Axon Scanner 4000B (Axon Instruments, Union City, CA, USA). The images were quantified by GENEPIX 6.0 software (Axon Instruments).

Two-sample $t$-test was applied to identify differentially expressed miRNAs between two groups (normal vs tumor; inflammatory breast cancer Vs noninflammatory breast cancer). The resulting $P$-values, computed from the $t$-test statistics, were then modeled by the Betat-Uniform Modeling algorithm to adjust for multiple hypothesis testing. The significant differentially expressed miRNAs were then identified based on appropriate false discovery rate cutoffs. The results were illustrated using unsupervised Hierarchical Cluster Analysis algorithm based on the identified miRNAs.

\section{Quantitative Reverse Transcription PCR Analysis}

The expression levels of miRNAs were detected by quantitative real-time PCR using TaqMan miRNA assays with individual miRNA-specific primers and probes (Life Technologies) to verify the microarray findings. TaqMan mature RNA-specific primers and probes precluded the detection of precursor miRNAs. Briefly, $10 \mathrm{ng}$ of total RNA was reverse transcribed in a volume of $15 \mu \mathrm{l}$ using TaqMan MicroRNA Reverse Transcription kit (Life Technologies). Quantitative PCR was performed with TaqMan Universal Master Mix (Life Technologies) using standard protocols on ABI Prism 7500 Sequence Detection System (Life Technologies). The mean cycle threshold was determined from triplicate reactions and U48 small nucleolar RNA (SNORD48) was used as endogenous control. Comparative cycle threshold method was used to compare expression levels.

\section{MiR205 In Situ Hybridization}

For each case, one whole-slide unstained tissue section $4 \mu \mathrm{m}$ thick that had been prepared from a representative paraffin block of primary invasive breast carcinoma was used for in situ hybridization by the institutional RNA Center. Briefly, the tissue slides were first digested with $15 \mu \mathrm{g} / \mathrm{ml}$ proteinase $\mathrm{K}$ for $10 \mathrm{~min}$ at room temperature, and then hybridized with the double-DIG-labeled mercury LNA microRNA probe (Exiqon, Woburn, MA, USA) for $2 \mathrm{~h}$ at $50^{\circ} \mathrm{C}$ on Ventana Discovery Ultra (Ventana Medical Systems, Tucson, AZ, USA). The digoxigenins were then detected with a polyclonal anti-DIG antibody and alkaline phosphataseconjugated second antibody (Ventana Medical Systems) using NBT-BCIP as the substrate. Raw images were captured with the same exposure and gain settings from all slides and saved as TIF files, and were analyzed using intensity measurement tools of Image-Pro Plus software (MediaCybernetics, Rockville, MD, USA).

\section{Immunohistochemistry}

The polymeric biotin-free horseradish peroxidase method was used for E-cadherin and vimentin immunohistochemical staining on a Leica Microsystems Bond Max stainer (Leica Microsystems, Buffalo Grove, IL, USA). In each case, one whole-slide unstained tissue section $4 \mu \mathrm{m}$ thick that had been prepared from a representative paraffin block of the invasive breast carcinoma was subjected to heat-induced epitope retrieval with Tris-EDTA buffer for $20 \mathrm{~min}$ at $100^{\circ} \mathrm{C}$ (E-cadherin) or citrate buffer for $5 \mathrm{~min}$ at $100^{\circ} \mathrm{C}$ (vimentin). Slides were then incubated with mouse monoclonal antibody to E-cadherin (clone HECD-1, 1:7000, Life Technologies) or vimentin (clone V9, 1:900, Dako North America, Carpinteria, CA, SA). The Refine Polymer Detection kit was used to detect bound antibody, with 3,3-diaminobenzidine serving as the chromogen (Leica Microsystems). Slides were counterstained with Mayer's hematoxylin. Results were evaluated with appropriate positive and negative tissue controls. For E-cadherin, membranous staining was considered positive. For vimentin, positive staining was defined as cytoplasmic staining in $>10 \%$ of invasive carcinoma cells.

\section{Statistical Analysis}

Statistical analysis was carried out using SAS version 9 (SAS Institute, Cary, NC, USA) and SPSS software (IBM, Armonk, NY, USA). Association between tumor type and clinicopathologic factors (Table 1) was assessed using Fisher's exact test. Comparisons of biomarker expression level between tumor and normal, inflammatory breast cancer and 
Table 1 Clinicopathologic features of tumor specimens used in microarray analysis

\begin{tabular}{|c|c|c|c|c|}
\hline $\begin{array}{l}\text { Clinicopathologic } \\
\text { features }\end{array}$ & $I B C(\mathrm{n}=23)$ & $\begin{array}{c}\text { Non-IBC } \\
(\mathrm{n}=24)\end{array}$ & $\begin{array}{l}\text { Total } \\
(\mathrm{n}=47)\end{array}$ & P-value \\
\hline \multicolumn{4}{|l|}{ Patient age (year) } & \multirow[t]{5}{*}{0.13} \\
\hline Min & 27 & 37 & 27 & \\
\hline Median & 54 & 63 & 57 & \\
\hline Mean & 54 & 62 & 58 & \\
\hline Max & 72 & 98 & 98 & \\
\hline \multicolumn{4}{|l|}{ Tumor type } & \multirow[t]{4}{*}{0.23} \\
\hline IDC & $22(96 \%)$ & $21(87 \%)$ & 43 & \\
\hline ILC & $0(0 \%)$ & $3(13 \%)$ & 3 & \\
\hline IMC & $1(4 \%)$ & $0(0 \%)$ & 1 & \\
\hline \multicolumn{4}{|c|}{ Lymphovascular invasion } & \multirow[t]{4}{*}{$>0.99$} \\
\hline Present & $9(39 \%)$ & $11(46 \%)$ & 20 & \\
\hline Absent & $11(48 \%)$ & $13(54 \%)$ & 24 & \\
\hline Unknown & $3(13 \%)$ & $0(0 \%)$ & 3 & \\
\hline \multicolumn{4}{|c|}{ Axillary lymph node status } & \multirow[t]{5}{*}{0.08} \\
\hline Negative & $6(26 \%)$ & $4(17 \%)$ & 10 & \\
\hline 1-3 positive & $4(17 \%)$ & $10(42 \%)$ & 14 & \\
\hline 4-9 positive & $7(30 \%)$ & $9(38 \%)$ & 16 & \\
\hline$\geq 10$ positive & $6(26 \%)$ & $1(4 \%)$ & 7 & \\
\hline \multicolumn{4}{|l|}{ ER status } & \multirow[t]{3}{*}{0.14} \\
\hline Positive ( $\geq 5 \%$ ) & $11(48 \%)$ & $17(71 \%)$ & 28 & \\
\hline Negative & $12(52 \%)$ & $7(29 \%)$ & 19 & \\
\hline \multicolumn{4}{|l|}{ PR status } & \multirow[t]{3}{*}{0.36} \\
\hline Positive $(\geq 5 \%)$ & $6(26 \%)$ & $10(42 \%)$ & 16 & \\
\hline \multirow{2}{*}{\multicolumn{4}{|c|}{ HER2 status }} & \\
\hline & & & & \multirow[t]{4}{*}{0.41} \\
\hline Positive & $4(17 \%)$ & $2(8 \%)$ & 6 & \\
\hline Negative & $18(78 \%)$ & $22(92 \%)$ & 40 & \\
\hline Unknown & $1(4 \%)$ & $0(0 \%)$ & 1 & \\
\hline \multicolumn{4}{|c|}{ Triple-negative status } & \multirow[t]{4}{*}{0.35} \\
\hline Yes & $9(39 \%)$ & $6(25 \%)$ & 15 & \\
\hline No & $13(57 \%)$ & $18(75 \%)$ & 31 & \\
\hline Unknown & $1(4 \%)$ & $0(\%)$ & 1 & \\
\hline \multicolumn{4}{|c|}{ Neoadjuvant chemotherapy } & \multirow[t]{3}{*}{1} \\
\hline Yes & $11(48 \%)$ & $11(46 \%)$ & 22 & \\
\hline No & $12(52 \%)$ & $13(54 \%)$ & 25 & \\
\hline \multicolumn{4}{|l|}{ Clinical stage } & \multirow[t]{3}{*}{0.08} \\
\hline $\begin{array}{l}\text { IIIB and below } \\
\text { (II, IIIA, IIIB) }\end{array}$ & $11(0,0,11)$ & $18(7,3,8)$ & 29 & \\
\hline $\begin{array}{l}\text { IIIC and above } \\
\text { (IIIC, IV) }\end{array}$ & $12(6,6)$ & $6(6,0)$ & 18 & \\
\hline \multicolumn{4}{|l|}{ Pathologic stage } & \multirow[t]{3}{*}{0.02} \\
\hline $\begin{array}{l}\text { IIIB and below } \\
\text { (II, IIIA, IIIB) }\end{array}$ & $10(0,0,10)$ & $19(5,10,4)$ & 29 & \\
\hline $\begin{array}{l}\text { IIIC and above } \\
\text { (IIIC, IV) }\end{array}$ & $13(7,6)$ & $5(5,0)$ & 18 & \\
\hline
\end{tabular}

Abbreviations: ER, estrogen receptor; IBC, inflammatory breast cancer; IDC, invasive ductal carcinoma; ILC, invasive lobular carcinoma; IMC, invasive mammary carcinoma with mixed ductal and lobular features; $\mathrm{PR}$, progesterone receptor.

noninflammatory breast cancer were carried out using Wilcoxon rank-sum test. Spearman's test was used to assess correlation between biomarker expression measured using different platforms. Overall survival represented duration between the initial breast cancer diagnosis and death from any cause or date of last follow-up. Distant metastasisfree survival represented duration between the initial breast cancer diagnosis and the point of distant metastasis. Survival end points were estimated and plotted using the Kaplan-Meier method. Comparisons of survival between patient groups were carried out using the log rank test. All tests were two sided and $P$-values of $\leq 0.05$ were considered statistically significant.

\section{Results}

\section{Patient Clinicopathologic Characteristics}

Total RNA isolated from fresh frozen tissue of the primary tumors of 23 inflammatory breast cancer, 24 noninflammatory breast cancer, and 12 normal breast tissue samples from 53 patients was subjected to miRNA microarray analysis. The clinicopathologic characteristics of the patients whose tumor samples were used are summarized in Table 1 . In all the clinicopathologic factors, except for pathologic stage, the inflammatory breast cancer and noninflammatory breast cancer groups did not show significant difference. The reason for the difference in pathologic stage was most likely because of the fact that inflammatory breast cancer patients were not restaged after neoadjuvant chemotherapy (especially the pT stage) as compared with noninflammatory breast cancer patients who were often downstaged after neoadjuvant treatment.

\section{Distinct MiRNA Expression in Breast Tumors by Microarray Analysis}

The heatmaps of miRNA expression comparing tumor with normal tissue samples showed distinct segregation (Figure 1). The 30 miRNAs that were most significantly different between tumor and normal samples based on $P$-value are listed in Table 2. For those that had been reported in previous expression profiling studies, the proposed functions in breast cancer are included in Table 2. However, of these 30 miRNAs, only 6 had a $P$-value of $<0.05$ between inflammatory breast cancer and noninflammatory breast cancer, all with very moderate fold changes, suggesting that inflammatory breast cancer shares many common changes in miRNA expression with noninflammatory breast cancer.

Examples of recently identified potential miRNA oncogenes and tumor suppressors and their expression profiles in our microarray analysis are summarized in Tables 3 and 4. Many but not all miRNAs reported in the literature were significantly different between tumor and normal tissue in our analysis. Because our cohort was devoid of early-stage breast cancer, it was not surprising that the miRNA profile obtained from our study did not entirely mirror those reported that were usually derived from breast tumors including all stages.

\section{Low MiR-205 Expression in Inflammatory Breast Cancer}

Although distinct clustering of miRNA expression was not identified between inflammatory breast 

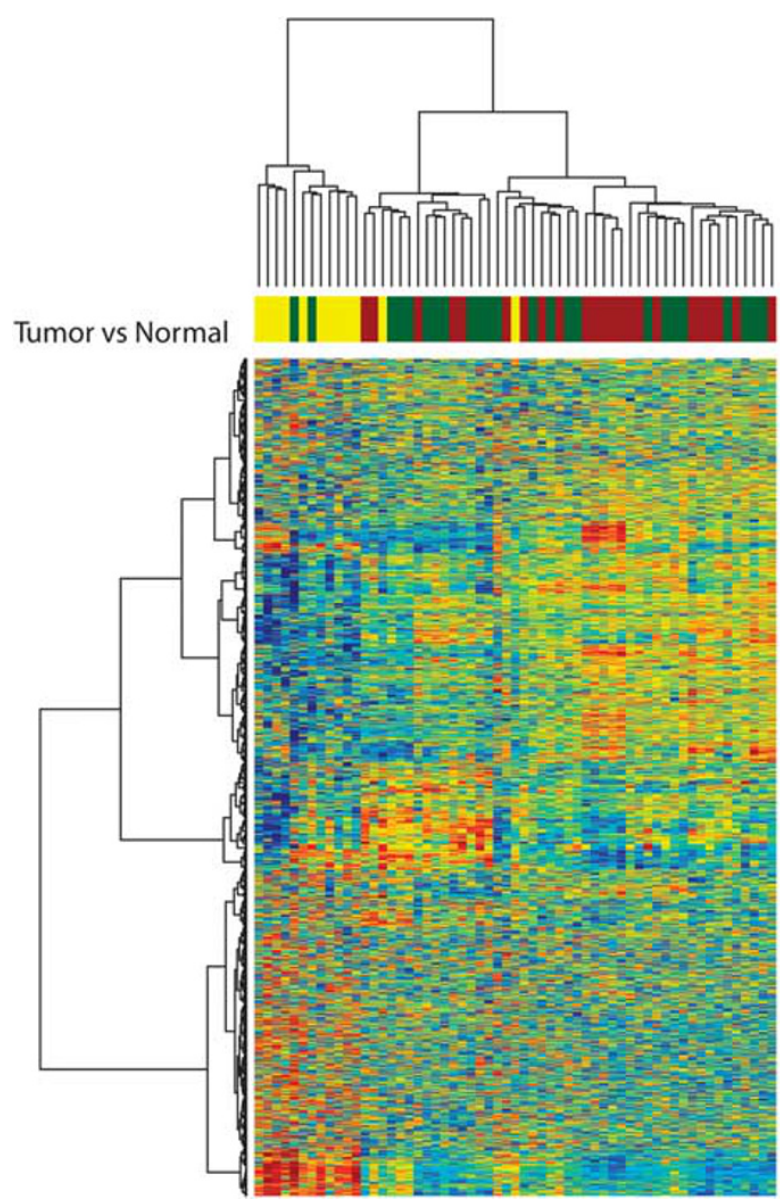
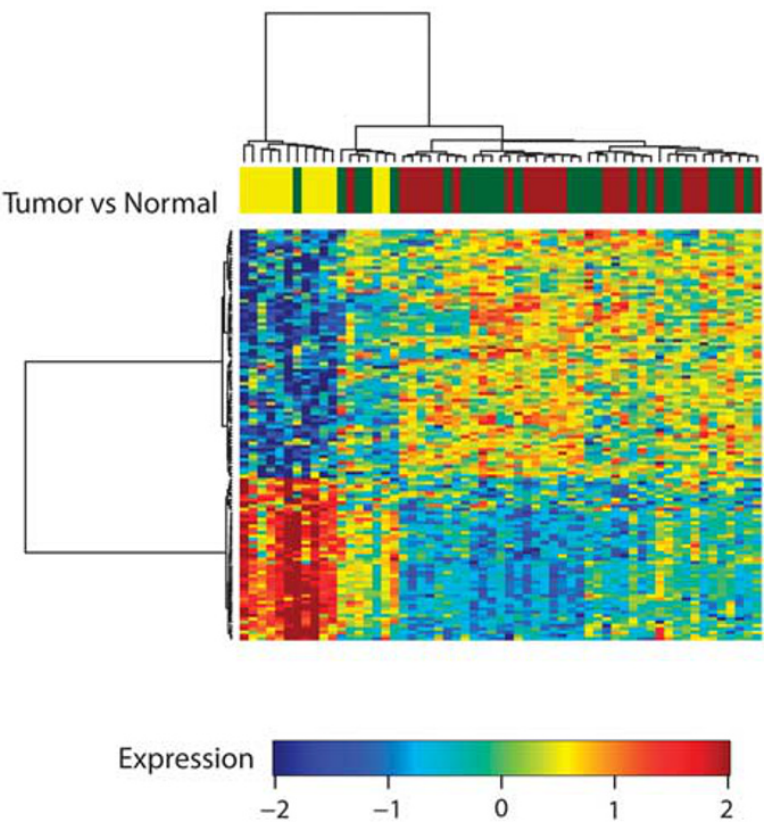

- IBC

- Non-IBC

$\square$ Normal

Figure 1 Heatmaps of miRNAs comparing tumor and normal samples. (Left) All 1827 probes; (right) at the false discovery rate level of $5 \mathrm{e}-05$ using two-sample $t$-test. IBC, inflammatory breast cancer.

cancer and noninflammatory breast cancer samples, several miRNAs were shown to be differentially expressed (Figure 2 and Table 5). MiR-205 was the most differentially expressed, with a 3.28-fold lower expression in inflammatory breast cancer $(P=0.001)$. MiR-205 was also expressed significantly lower in tumor compared with normal tissue $(P=0.001,4.06$-fold $)$. Quantitative real-time RT-PCR was performed on eight of the miRNAs in Table 5 selected based on fold change, $P$-value, and expression levels. The results are shown in Table 6 . MiR-205 expression was significantly downregulated in tumor tissue compared with normal tissue, as well as in inflammatory breast cancer compared with noninflammatory breast cancer.

\section{Lower Expression of MiR-205 Was Associated with Poor Prognosis}

The distant metastasis-free survival and overall survival were assessed in patients according to the miR-205 expression levels in all 47 tumors. Follow-up time ranged from 3 months to 159 months (median follow-up: 39 months). As shown in Figure 3, lower miR-205 expression was associated with shorter distant metastasis-free survival $(P=0.012)$ and overall survival $(P=0.025)$.

\section{MiR-205 In Situ Hybridization Analysis}

To further confirm that the difference of miR-205 between inflammatory breast cancer and noninflammatory breast cancer was due to differential expression in the epithelial cells, in situ hybridization of miR-205 was performed on formalin-fixed, paraffin-embedded tissue of breast tumors. In all, 15 noninflammatory breast cancer and 8 inflammatory breast cancer samples used for microarray analysis had available formalin-fixed, paraffin-embedded tissue. Formalinfixed, paraffin-embedded tissue from six additional inflammatory breast cancer patients was also included.

Tumor sections containing nonneoplastic breast epithelium in the same sections were selected for in situ hybridization. Staining results of representative cases of inflammatory breast cancer and noninflammatory breast cancer are shown in Figure 4. In the nonneoplastic breast epithelium, strong staining in the basal/myoepithelial cell portion was observed in each case (Figure $4 \mathrm{~d}-\mathrm{f}$ and $\mathrm{j}-\mathrm{l}$ ), consistent with previous reports. ${ }^{58,59}$ The invasive carcinoma cells had 
Table 2 Top 30 differentially expressed miRNA molecules comparing tumor and normal samples based on $P$-value $(P<6.0 \mathrm{E}-08)$

\begin{tabular}{|c|c|c|c|c|c|c|}
\hline Name & $\begin{array}{l}\text { Trend } \\
\text { tumor vs } \\
\text { normal }\end{array}$ & $\begin{array}{l}\text { Fold change } \\
\text { tumor vs } \\
\text { normal }\end{array}$ & $\begin{array}{l}\text { P-value } \\
\text { IBC vs non- } \\
I B C\end{array}$ & $\begin{array}{c}\text { Fold change IBC } \\
\text { vs non-IBC if } \\
\mathrm{P}<0.05\end{array}$ & $\begin{array}{l}\text { Reported function in breast } \\
\text { cancer tissue/cells }\end{array}$ & References \\
\hline $\mathrm{miR}-23 \mathrm{~b} / 27 \mathrm{~b}$ & & & & & $\begin{array}{l}\text { Pro-metastasis, associated with } \\
\text { poor prognosis }\end{array}$ & 33,34 \\
\hline miR-23b* & Up & 3.04 & 0.025 & 1.32 & & \\
\hline $\mathrm{miR}-125 \mathrm{a} / \mathrm{b}$ & & & & & Antiproliferation & $22,23,25,35-45$ \\
\hline miR-125a-5p & Down & -2.15 & 0.012 & -1.29 & & \\
\hline miR-125a-3p & Down & -2.26 & 0.807 & & & \\
\hline $\operatorname{miR}-185$ & $\mathrm{Up}$ & 2.77 & 0.509 & & Antiproliferation & 22 \\
\hline $\operatorname{miR}-210$ & $\mathrm{Up}$ & 3.23 & 0.234 & & Anti-apoptosis, pro-angiogenesis & $\begin{array}{l}21-23,25,35,38, \\
44-46\end{array}$ \\
\hline miR-210MM1G/T & Up & 4.02 & 0.632 & & & \\
\hline miR-210MM2GA/TC & Up & 3.62 & 0.580 & & & \\
\hline miR-212 & Down & -1.87 & 0.043 & -1.21 & Not reported & \\
\hline miR-338-3p & Up & 3.21 & 0.260 & & $\begin{array}{l}\text { (only reported as circulating } \\
\text { miRNA) }\end{array}$ & \\
\hline $\operatorname{miR}-448$ & Down & -1.88 & 0.195 & & $\begin{array}{l}\text { Associated with chemotherapy- } \\
\text { induced EMT }\end{array}$ & 47 \\
\hline miR-526b & $\mathrm{Up}$ & 8.04 & 0.794 & & Not reported & \\
\hline $\operatorname{miR}-629 *$ & $\mathrm{Up}$ & 2.00 & 0.084 & & $\begin{array}{l}\text { Upregulated in multiple cancer } \\
\text { types including breast, function } \\
\text { unknown }\end{array}$ & 48 \\
\hline miR-662 & Up & 3.24 & 0.490 & & Not reported & \\
\hline miR-891a & Down & -2.46 & 0.084 & & Not reported & \\
\hline miR-922 & Up & 3.96 & 0.381 & & Not reported & \\
\hline $\operatorname{miR}-1226$ & Down & -2.24 & 0.017 & -1.28 & Proapoptosis & 49 \\
\hline $\operatorname{miR}-1226^{*}$ & Down & -1.88 & 0.131 & & Not reported & \\
\hline $\operatorname{miR}-1236$ & Down & -2.18 & 0.136 & & Not reported & \\
\hline miR-1243 & Down & -2.29 & 0.051 & & Not reported & \\
\hline miR-1244 & Down & -2.12 & 0.061 & & Not reported & \\
\hline miR-1255a & Down & -2.24 & 0.030 & -1.24 & Not reported & \\
\hline $\operatorname{miR}-1255 b$ & Down & -2.26 & 0.210 & & Not reported & \\
\hline miR-1260 & $\mathrm{Up}$ & 2.47 & 0.473 & & $\begin{array}{l}\text { (only reported as circulating } \\
\text { miRNA) }\end{array}$ & \\
\hline $\operatorname{miR}-1260 b$ & Up & 2.39 & 0.101 & & Not reported & \\
\hline $\operatorname{miR}-1262$ & Down & -2.15 & 0.067 & & Not reported & \\
\hline $\operatorname{miR}-1263$ & Down & -2.43 & 0.035 & -1.26 & Not reported & \\
\hline $\operatorname{miR}-1289$ & Down & -2.94 & 0.062 & & Not reported & \\
\hline miR-1910 & Up & 1.81 & 0.056 & & Not reported & \\
\hline $\operatorname{miR}-3140$ & Down & -2.68 & 0.263 & & Not reported & \\
\hline miR-3197 & Up & 1.95 & 0.197 & & Not reported & \\
\hline
\end{tabular}

$P$-values of $\leq 0.05$ in bold.

predominantly cytoplasmic staining. Although staining of the nucleus was inconspicuous, nucleolar staining was readily seen in most of the cases. The staining intensity of the invasive carcinomas varied greatly from case to case. In the majority of the cases, heterogeneity in staining intensity was not detected within each case. In rare cases, scattered strongly stained tumor cells were seen intermixed with lightly stained cells (Figure 4i). The relative staining intensity of the tumors was quantitated using the Image-Pro Plus software (Figure 5). Inflammatory breast cancer tumors (mean \pm s.d., $54 \pm 20$; $n=14$ ) had lower staining compared with noninflammatory breast cancer tumors (mean \pm s.d., $72 \pm 18$; $n=15)(P=0.04$; Figure $4 \mathrm{a}-\mathrm{c}$ and g-i). No difference was detected between the pretreatment samples (mean \pm s.d., $65 \pm 21 ; n=13$ ) and postchemotherapy samples (mean \pm s.d., $62 \pm 22 ; n=16)(P=0.71)$. The two cases of invasive lobular carcinoma had miR-205 expression values of 66 and 78, respectively.
The staining intensity in the luminal epithelial cells was light to moderate compared with the myoepithelial cells (Figure $4 \mathrm{~d}-\mathrm{f}$ and $\mathrm{j}-\mathrm{l}$ ). Stromal fibroblasts, blood vessels, and lymphoplasmacytic cells showed light staining in most of the cases and moderate staining in a few cases. Adipose tissue appeared to have light staining in all cases.

To examine whether the significant differences in miR-205 expression by microarray, qPCR, and in situ hybridization were coincidental, Spearman's correlation test was performed in order to evaluate correlation among the three platforms. Significant association was seen in the 53 samples used in both the microarray assay and qPCR $(r=-0.8, P<0.0001$; Figure 6a) and the 23 tumors used in qPCR and in situ hybridization ( $r=-0.5, P=0.02$; Figure $6 \mathrm{~b})$. Hence, the differences in miR-205 expression using the three platforms were in good agreement. 
Table 3 Oncogene or poor prognostic indicator in breast cancer based on literature review

\begin{tabular}{|c|c|c|c|c|c|}
\hline \multirow[b]{2}{*}{$\operatorname{MiRNA}$} & \multirow[b]{2}{*}{ References } & \multirow[b]{2}{*}{ Function/association } & \multicolumn{3}{|c|}{ Current study } \\
\hline & & & $\begin{array}{l}\mathrm{P} \text {-value tumor } \\
\text { vs normal }\end{array}$ & $\begin{array}{c}\text { Fold change } \\
\text { tumor vs } \\
\text { normal }\end{array}$ & $\begin{array}{l}\text { Trend tumor vs } \\
\text { normal if } \\
\mathrm{P}<0.05\end{array}$ \\
\hline miR-9 & $21,22,35,36,45,46,50$ & Pro-metastasis & 0.998 & -1.00 & \\
\hline miR-10b & $21-23,25,36,40,41,44,45,51$ & Pro-metastasis & 0.001 & -2.75 & Down \\
\hline miR-17-92 cluster (-17,- & $22,23,35,36,40-45,51-54$ & Pro-metastasis & & & \\
\hline \multicolumn{6}{|l|}{$18 a,-19 a,-19 b-1,-20 a,-92 a-1)$} \\
\hline miR-17 & & & 0.139 & 1.44 & \\
\hline $\operatorname{miR}-18 a$ & & & 0.178 & -1.60 & \\
\hline miR-19a & & & 0.0004 & 2.00 & Up \\
\hline miR-20a & & & 0.062 & 1.72 & \\
\hline miR-19b-1 & & & 0.106 & 1.80 & \\
\hline miR-92a-1* & & & 0.022 & 1.72 & Up \\
\hline $\operatorname{miR}-21$ & $\begin{array}{l}21-23,25,35-37,39,40-46 \\
50-52,54,55\end{array}$ & $\begin{array}{l}\text { Anti-apoptosis, } \\
\text { pro-metastasis }\end{array}$ & $<0.0001$ & 4.50 & $\mathrm{Up}$ \\
\hline $\operatorname{miR}-27$ & $22,23,35,36,40-45$ & $\begin{array}{l}\text { Pro-proliferation; } \\
\text { angiogenesis }\end{array}$ & & & \\
\hline miR-27a & & & 0.083 & 1.52 & \\
\hline $\operatorname{miR}-29$ & $21,25,41,42,45$ & Pro-metastasis & & & \\
\hline miR-29a & & & 0.002 & -1.72 & Down \\
\hline miR-29b & & & 0.314 & 1.32 & \\
\hline miR-29c & & & 0.207 & -1.44 & \\
\hline $\operatorname{miR}-103 / 107$ & $21,23,45,55$ & Pro-metastasis & & & \\
\hline miR-103 & & & 0.136 & 1.49 & \\
\hline miR-107 & & & 0.104 & 1.53 & \\
\hline miR-106b/93/25 cluster & $25,36,42,45,46,54$ & Pro-proliferation & & & \\
\hline miR-106b & & & 0.031 & 1.60 & Up \\
\hline miR-93 & & & 0.0004 & 2.74 & Up \\
\hline miR-25 & & & 0.324 & -1.31 & \\
\hline miR-128 & $22,35,40,44$ & Pro-metastasis & 0.225 & 1.37 & \\
\hline $\operatorname{miR}-144$ & 35 & Pro-proliferation & 0.151 & -1.70 & \\
\hline $\operatorname{miR}-155$ & $\begin{array}{l}22,23,25,35-37,39-45,50, \\
54,56\end{array}$ & $\begin{array}{l}\text { Pro-metastasis, } \\
\text { angiogenesis, anti-apoptosis }\end{array}$ & 0.010 & 1.61 & Up \\
\hline $\operatorname{miR}-181 \mathrm{a}$ & 56 & Inhibit anoikis & 0.013 & 1.93 & Up \\
\hline miR-183/96/182 cluster & $40,54,56$ & $\begin{array}{l}\text { Pro-proliferation; pro- } \\
\text { metastasis }\end{array}$ & & & \\
\hline miR-183 & & & 0.294 & -1.35 & \\
\hline miR-96 & & & 0.777 & 1.07 & \\
\hline miR-182 & & & 0.003 & 3.94 & $\mathrm{Up}$ \\
\hline $\operatorname{miR}-191$ & $22,25,45,56$ & Pro-proliferation & $<0.0001$ & 3.15 & Up \\
\hline miR-196a & $22,25,42,45$ & Pro-metastasis & 0.009 & 1.81 & $\mathrm{Up}$ \\
\hline $\operatorname{miR}-206$ & $\begin{array}{l}21-23,35,36,40,42-44,52, \\
53,55\end{array}$ & $\begin{array}{l}\text { Pro-metastasis; estrogen } \\
\text { unresponsiveness }\end{array}$ & 0.037 & 1.31 & Up \\
\hline $\operatorname{miR}-210$ & $21-23,25,35,38,44-46$ & Anti-apoptosis, angiogenesis & $<0.0001$ & 3.23 & $\mathrm{Up}$ \\
\hline miR-221/222 & $22,36,45,52,53,56$ & $\begin{array}{l}\text { Pro-metastasis, pro- } \\
\text { proliferation }\end{array}$ & & & \\
\hline miR-221 & & & 0.039 & -1.67 & Down \\
\hline $\mathrm{miR}-221 * \mathrm{MM} 1 \mathrm{C} / \mathrm{G}$ & & & 0.001 & -3.31 & Down \\
\hline miR-222 & & & 0.318 & 1.28 & \\
\hline $\operatorname{miR}-301$ & 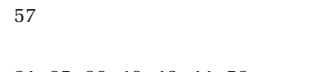 & $\begin{array}{l}\text { Associated with distant } \\
\text { metastasis }\end{array}$ & 0.007 & -2.09 & Down \\
\hline miR-373/520c & $21,35,36,40,42,44,50$ & Pro-metastasis & & & \\
\hline miR-373 & & & 0.261 & -1.30 & \\
\hline miR-520c & & & 0.323 & 1.38 & \\
\hline $\operatorname{miR}-766$ & 46 & $\begin{array}{l}\text { Associated with decreased } \\
\text { survival }\end{array}$ & $<0.0001$ & 1.46 & $\mathrm{Up}$ \\
\hline
\end{tabular}

$P$-values of $\leq 0.05$ in bold.

\section{Immunohistochemical Staining of E-Cadherin and Vimentin}

It has been shown that miR-205 targets the transcription repressors of E-cadherin, ZEB1, and ZEB2 in cultured cells, ${ }^{60,61}$ thereby regulating epithelialmesenchymal transition. Thus, in inflammatory breast cancer, low miR-205 expression is expected to lead to downregulation of E-cadherin. However, it has been reported that inflammatory breast cancers express high levels of E-cadherin compared with noninflammatory breast cancers. ${ }^{62,63}$ In light of the high rate of metastasis of inflammatory breast cancer that would correlate with active epithelial-mesenchymal transition, these 
Table 4 Tumor suppressor or good prognostic indicator in breast cancer based on literature review

\begin{tabular}{|c|c|c|c|c|c|}
\hline \multirow[b]{2}{*}{ MiRNA } & \multirow[b]{2}{*}{ References } & \multirow[b]{2}{*}{ Function/association } & \multicolumn{3}{|c|}{ Current study } \\
\hline & & & $\begin{array}{l}\text { P-value } \\
\text { tumor vs } \\
\text { normal }\end{array}$ & $\begin{array}{c}\text { Fold change } \\
\text { tumor vs } \\
\text { normal }\end{array}$ & $\begin{array}{c}\text { Trend tumor } \\
\text { vs normal if } \\
\mathrm{P}<0.05\end{array}$ \\
\hline Let-7 & $22,23,25,35-37,42-46,50-52,55$ & $\begin{array}{l}\text { Antiproliferation, anti- } \\
\text { metastasis }\end{array}$ & & & \\
\hline Let-7a & & & 0.944 & 1.01 & \\
\hline Let-7a-2-3p & & & 0.0004 & -2.94 & Down \\
\hline Let-7b & & & 0.551 & -1.10 & \\
\hline Let-7c & & & 0.948 & -1.01 & \\
\hline Let-7d & & & 0.719 & 1.07 & \\
\hline Let-7e & & & 0.625 & 1.04 & \\
\hline Let-7f & & & 0.309 & -1.24 & \\
\hline Let-7g & & & 0.144 & -1.19 & \\
\hline Let-7i & & & 0.446 & -1.06 & \\
\hline $\mathrm{miR}-15 \mathrm{a} / 16$ & 22 & Proapoptosis & & & \\
\hline miR-15a & & & 0.401 & -1.17 & \\
\hline miR-16 & & & 0.011 & 2.00 & Up \\
\hline $\operatorname{miR}-26 a$ & 35,56 & $\begin{array}{l}\text { Proapoptosis, antiproliferation } \\
\text { and anti-metastasis }\end{array}$ & 0.104 & -1.58 & \\
\hline miR-30 family & $21,36,42,45,46,55$ & Antiproliferation & & & \\
\hline miR-30a & & & 0.834 & -1.05 & \\
\hline miR-30b & & & 0.426 & 1.25 & \\
\hline miR-30c & & & 0.522 & 1.22 & \\
\hline mir-30d & & & 0.643 & 1.13 & \\
\hline miR-30e & & & 0.496 & 1.19 & \\
\hline miR-30-3p & & & 0.006 & -2.28 & Down \\
\hline $\operatorname{miR}-31$ & $21,22,25,35,36,40,42,44,45,55$ & Proapoptosis, anti-metastasis & 0.16 & 1.43 & \\
\hline $\operatorname{miR}-34 a$ & $23,36,37,42,44,46,52$ & Proapoptosis, antiproliferation & 0.0006 & 2.28 & Up \\
\hline miR-101 & 22,42 & Anti-metastasis & 0.005 & -2.29 & Down \\
\hline miR-122 & 22,37 & Antiproliferation & 0.095 & -1.14 & \\
\hline $\mathrm{miR}-125 \mathrm{a} / \mathrm{b}$ & $22,23,25,35-45$ & Antiproliferation & & & \\
\hline miR-125a & & & $<0.0001$ & -2.15 & Down \\
\hline miR-125b & & & 0.001 & -2.27 & Down \\
\hline $\operatorname{miR}-126$ & $21,22,35,36,40,42-46,54,56$ & $\begin{array}{l}\text { Anti-metastasis, } \\
\text { antiproliferation }\end{array}$ & 0.002 & -1.90 & Down \\
\hline $\operatorname{miR}-130$ & 25,53 & $\begin{array}{l}\text { Anti-metastasis, } \\
\text { antiproliferation }\end{array}$ & & & \\
\hline miR-130a & & & 0.038 & -1.88 & Down \\
\hline miR-130b & & & $<0.0001$ & -1.83 & Down \\
\hline $\operatorname{miR}-135 a$ & 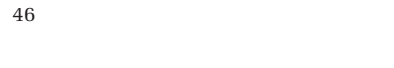 & $\begin{array}{l}\text { Associated with decreased } \\
\text { metastasis }\end{array}$ & 0.004 & -1.72 & Down \\
\hline $\operatorname{miR}-145$ & $22,23,25,36,38-45,50-54,56$ & $\begin{array}{l}\text { Proapoptosis, anti-metastasis, } \\
\text { suppresses angiogenesis }\end{array}$ & $<0.0001$ & -2.06 & Down \\
\hline $\operatorname{miR}-146$ & 22,45 & Anti-metastasis & & & \\
\hline miR-146a & & & 0.169 & 1.62 & \\
\hline miR-146b & & & 0.032 & 1.61 & Up \\
\hline $\operatorname{miR}-185$ & 22 & Antiproliferation & $<0.0001$ & 2.77 & $\mathrm{Up}$ \\
\hline $\operatorname{miR}-193 \mathrm{~b}$ & 21,44 & Antiproliferation & 0.0003 & 1.92 & $\mathrm{Up}$ \\
\hline miR-200 family & $21,23,36,40,42-46,51,53,54,57$ & Antiproliferation & & & \\
\hline miR-200a & & & 0.002 & 3.26 & Up \\
\hline miR-200b & & & $<0.0001$ & 6.01 & $\mathrm{Up}$ \\
\hline miR-200c & & & 0.023 & 2.17 & $\mathrm{Up}$ \\
\hline $\operatorname{miR}-141$ & & & $<0.0001$ & 2.89 & $\mathrm{Up}$ \\
\hline miR-429 & & & $<0.0001$ & 3.34 & Up \\
\hline miR-205 & $22,23,25,36,37,40,42,45,51,52,54$ & Anti-metastasis & 0.001 & -4.06 & Down \\
\hline miR-206 & $23,42-45$ & Antiproliferation, anti-invasion & 0.037 & 1.31 & Up \\
\hline $\operatorname{miR}-302 \mathrm{c}$ & 44 & Antiproliferation & 0.136 & -1.68 & \\
\hline $\operatorname{miR}-326$ & $22,25,42$ & Regulates multidrug resistance & $<\mathbf{0 . 0 0 0 1}$ & 2.09 & Up \\
\hline $\operatorname{miR}-335$ & $21,35,36,40,42-46$ & Anti-invasion/metastasis & 0.100 & -1.85 & \\
\hline $\operatorname{miR}-342-5 p$ & 46,56 & $\begin{array}{l}\text { Antiproliferation, associated } \\
\text { with decreased metastasis }\end{array}$ & 0.0003 & 1.56 & Up \\
\hline $\operatorname{miR}-497$ & $25,35,40,46,56$ & Proapoptosis, antiproliferation & 0.352 & 1.12 & \\
\hline $\operatorname{miR}-563$ & 46 & $\begin{array}{l}\text { Associated with increased } \\
\text { survival }\end{array}$ & 0.154 & -1.77 & \\
\hline $\operatorname{miR}-1226$ & 22 & Proapoptosis & $<0.0001$ & -2.24 & Down \\
\hline $\operatorname{miR}-1539$ & 46 & $\begin{array}{l}\text { Associated with increased } \\
\text { survival }\end{array}$ & 0.065 & 1.84 & \\
\hline
\end{tabular}

$P$-values of $\leq 0.05$ in bold. 

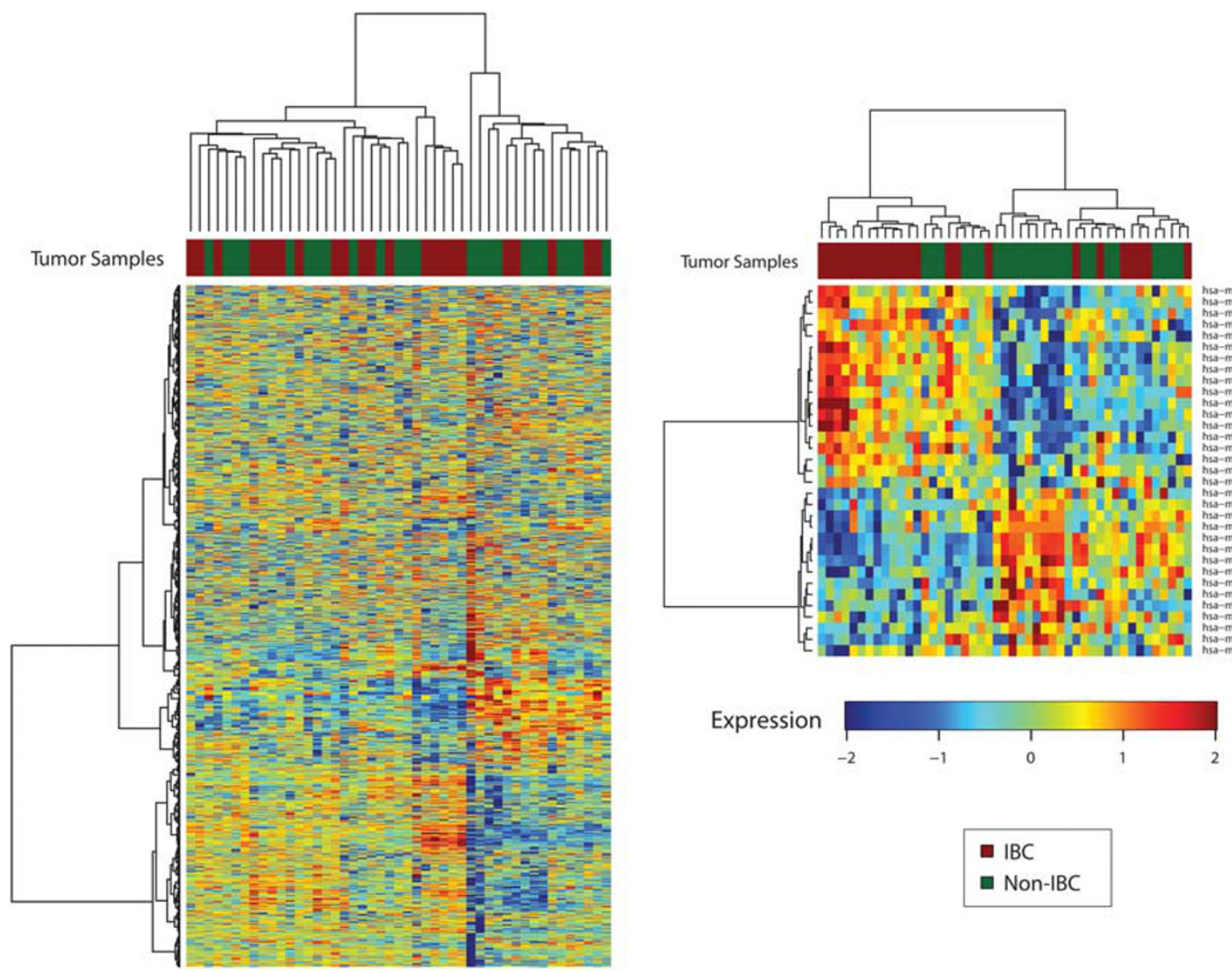

Figure 2 Heatmaps of miRNAs comparing inflammatory breast cancer (IBC) and non-IBC. (Left) All 1827 probes; (right) at the false discovery rate level of 0.1 .

Table 5 Top 20 differentially expressed miRNA molecules comparing inflammatory breast cancer and noninflammatory breast cancer at false discovery rate of $0.1(P<0.003427)$

\begin{tabular}{llrllr}
\hline & $\begin{array}{c}\text { P-value } \\
\text { IBC vs } \\
\text { non- } \\
\text { IBC }\end{array}$ & $\begin{array}{c}\text { Fold } \\
\text { change } \\
\text { IBC vs } \\
\text { non-IBC }\end{array}$ & $\begin{array}{c}\text { Trend } \\
\text { IBC vs } \\
\text { non- } \\
\text { IBC }\end{array}$ & $\begin{array}{c}\text { P-value } \\
\text { tumor vs } \\
\text { normal }\end{array}$ & $\begin{array}{c}\text { Fold } \\
\text { change } \\
\text { tumor vs } \\
\text { normal }\end{array}$ \\
\hline miR-23a & 0.002 & -1.87 & Down & 0.564 & -1.15 \\
miR-23b & 0.0005 & -1.94 & Down & 0.484 & -1.17 \\
miR-29b-1* & 0.002 & -1.58 & Down & 0.160 & 1.35 \\
miR-135a & 0.0003 & -1.67 & Down & 0.004 & -1.72 \\
miR-139-3p & 0.003 & 1.26 & Up & 0.001 & 1.35 \\
miR-183* & 0.0005 & -2.28 & Down & 0.005 & 2.29 \\
miR-205 & 0.001 & -3.28 & Down & 0.001 & -4.06 \\
miR-221 & 0.003 & -1.89 & Down & 0.039 & -1.67 \\
miR-342-5p & 0.0005 & 1.36 & Up & 0.0003 & 1.56 \\
miR-423-5p & 0.003 & 1.39 & Up & 0.058 & 1.26 \\
miR-453 & 0.0007 & 1.71 & Up & $<0.0001$ & 2.35 \\
miR-515-3p & 0.003 & -1.96 & Down & 0.024 & -1.77 \\
miR-624* & 0.001 & -2.63 & Down & 0.056 & -2.04 \\
miR-654-5p & 0.001 & 1.51 & Up & 0.0007 & 2.31 \\
miR-1249 & 0.0002 & -1.32 & Down & 0.432 & -1.07 \\
mir-1908 & 0.0001 & 1.54 & Up & 0.083 & 1.32 \\
miR-3147 & 0.003 & 1.42 & Up & 0.040 & 1.31 \\
miR-4296 & 0.003 & 1.53 & Up & 0.015 & 1.63 \\
miR-4317 & 0.0009 & -1.83 & Down & 0.084 & -1.45 \\
miR-4321 & 0.002 & 1.93 & Up & 0.0008 & 2.40 \\
\hline & & & & & \\
\hline
\end{tabular}

previously reported results appear in conflict. Therefore, it is of interest to examine the association between miR-205 and E-cadherin expression in the inflammatory breast cancer samples. Vimentin is a marker of mesenchymal cells that is infrequently expressed in epithelial tumors, and the expression in the latter suggests mesenchymal features or epithelialmesenchymal transition. Formalin-fixed, paraffinembedded tissue of eight tumors representing different miR-205 expression levels by in situ hybridization intensities was selected to stain for E-cadherin and vimentin by immunohistochemistry. All tumors except for one case of noninflammatory breast cancer were histologically of ductal differentiation. The single invasive lobular carcinoma was expected to be negative for E-cadherin, whereas others were expected diffusely positive. The staining results are shown in Figure 7. As expected, the case of invasive lobular carcinoma was negative for E-cadherin (Figure 7j). Interestingly, one inflammatory breast cancer and one non-inflammatory breast cancer had markedly decreased E-cadherin staining, with positive staining in small patchy areas intermixed with negatively stained areas (Figure $7 \mathrm{~d}$ and $\mathrm{k}$ ). Both tumors had 
Table 6 Quantitative PCR results on eight miRNAs comparing inflammatory breast cancer and noninflammatory breast cancer samples

\begin{tabular}{|c|c|c|c|c|c|c|}
\hline & \multicolumn{6}{|c|}{ qPCR normalized Ct value } \\
\hline & Normal $(\mathrm{n}=11)$ & Tumor $(\mathrm{n}=45)$ & $I B C(\mathrm{n}=21)$ & Non-IBC $(\mathrm{n}=24)$ & P-value tumor vs normal & P-value $I B C$ vs non-IBC \\
\hline miR-23b & 3.87 & 4.61 & 4.65 & 4.59 & 0.09 & 0.92 \\
\hline miR-135a & 5.86 & 7.79 & 8.34 & 7.31 & 0.006 & 0.08 \\
\hline miR-205 & -0.44 & 2.33 & 3.22 & 1.55 & 0.0007 & 0.02 \\
\hline miR-515-3p & $-^{\mathrm{a}}$ & & & & & \\
\hline miR-139-3p & 8.41 & 11.88 & 12.31 & 11.52 & $<0.0001$ & 0.17 \\
\hline miR-342-5p & 7.75 & 7.96 & 8.37 & 7.60 & 0.41 & 0.06 \\
\hline $\operatorname{miR}-423-5 p$ & 4.17 & 4.83 & 4.92 & 4.76 & 0.06 & 0.7 \\
\hline $\operatorname{miR}-453$ & $-^{\mathrm{a}}$ & & & & & \\
\hline
\end{tabular}

${ }^{\mathrm{a} C y c l e}$ threshold (Ct) values too high for meaningful interpretation.

$P$-values of $\leq 0.05$ in bold.

a

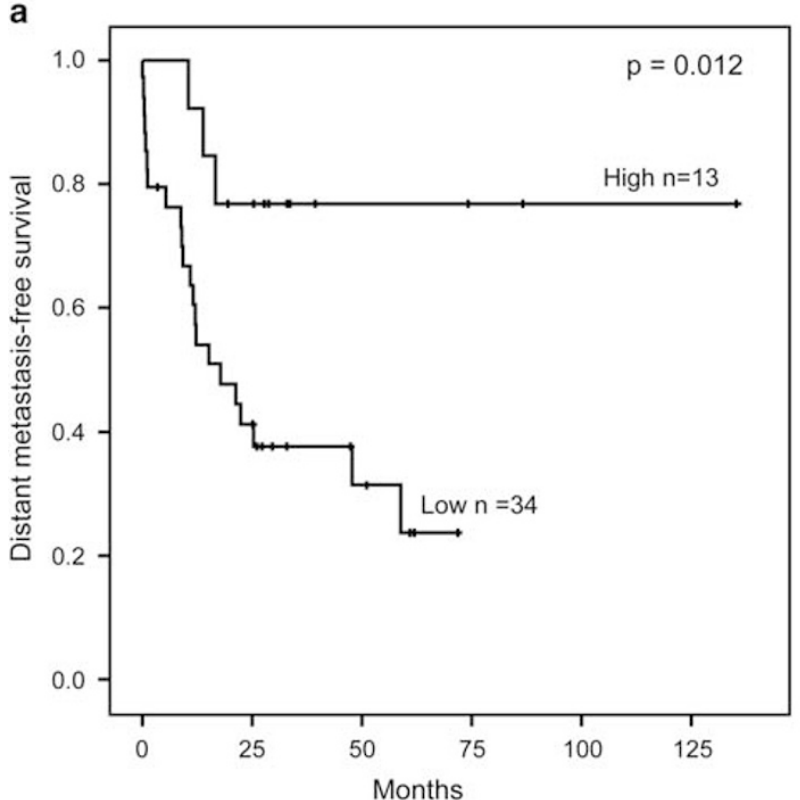

b

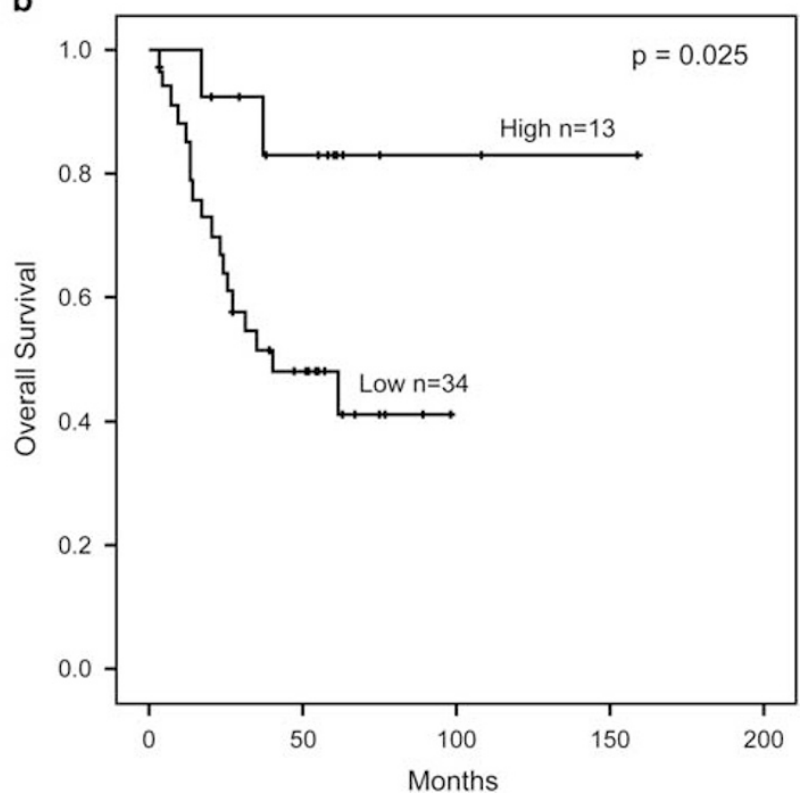

Figure 3 Lower miR-205 expression is associated with shorter distant metastasis-free survival and overall survival in patients with breast cancer. (a) Kaplan-Meier plots of distant metastasis-free survival between tumors with high and low miR-205 expression levels. (b) Kaplan-Meier plots of overall survival between tumors with high and low miR-205 expression levels.

relatively low miR-205 by in situ hybridization. However, not all cases with low miR-205 had decreased staining for E-cadherin. In addition, both cases with decreased E-cadherin staining and one case with diffuse strong E-cadherin staining showed positive staining for vimentin (Figure $7 f, h$ and o). Therefore, some ductal tumors can have decreased expression of miR205 and E-cadherin, regardless of inflammatory breast cancer phenotypes.

\section{Discussion}

The current study demonstrated a clear segregation and differential expression of microRNAs between breast tumor and normal samples. The miR-205 expression was significantly lower in inflammatory breast cancer compared with noninflammatory breast cancer tumors by microarray and qPCR analyses of fresh tissue, and by in situ hybridization on formalin-fixed, paraffin-embedded tissue. Lower expression of miR-205 was associated with shorter distant metastasis-free survival and overall survival. Further studies are warranted to explore miR-205 as a potential target for inflammatory breast cancer.

Two miRNA profiling studies on inflammatory breast cancer by quantitative RT-PCR have been previously reported. ${ }^{64,65}$ In one study, the authors evaluated the expression of 384 miRNAs in 20 inflammatory breast cancer and 50 noninflammatory breast cancer fresh frozen samples, and identified 13 miRNAs whose expression levels were different between inflammatory breast cancer and noninflammatory breast cancer, including 6 with increased expression in inflammatory breast cancer (miR-335, miR-337-5p, miR-451, miR-486-3p, miR-520a-5p, 
IBC
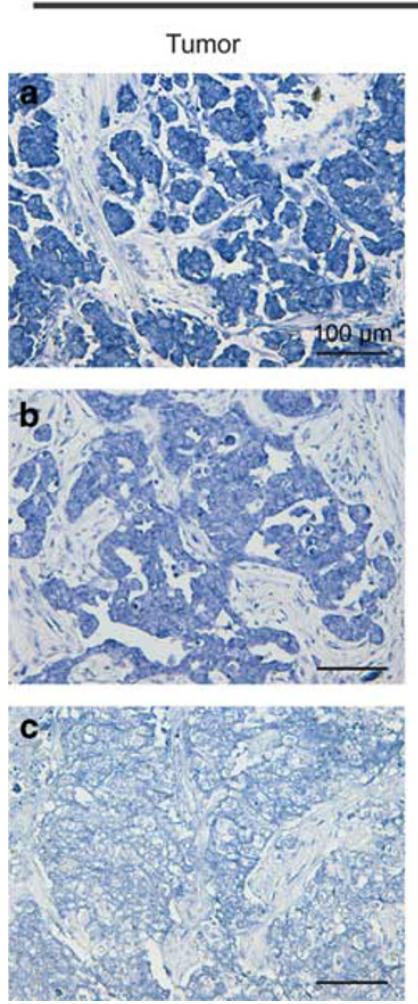
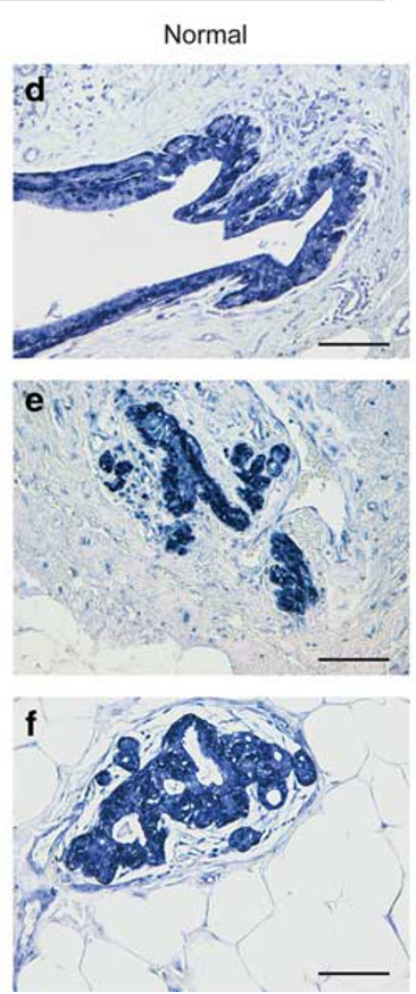

Non-IBC
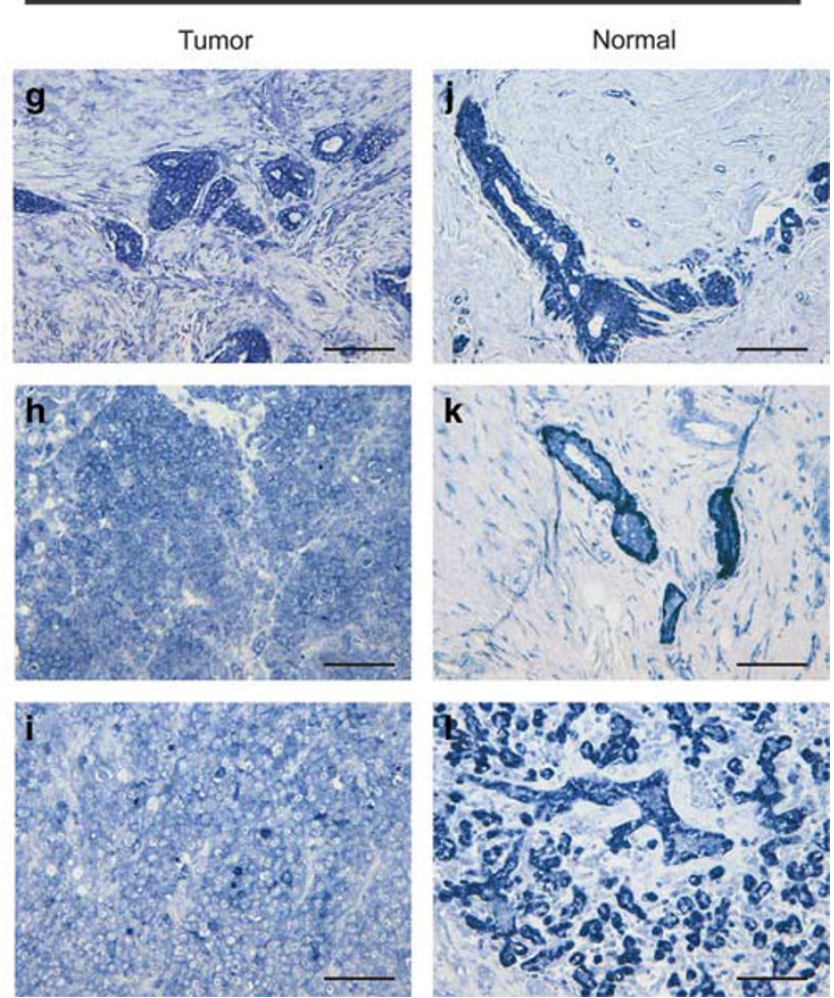

Figure 4 MiR-205 in situ hybridization. Blue represents positive staining. (a-c) and (g-i) are in descending order of staining intensity, respectively. The cases shown in this figure are indicated by arrows in Figure 5. (a-c) Representative inflammatory breast cancer (IBC) cases. (d-f) Staining of the corresponding normal breast epithelium on the same sections of the IBC tumors to their left. (g-i) Representative non-IBC cases. (j-l) Staining of the corresponding normal breast epithelium on the same sections of the non-IBC tumors to their left.

and miR-548d-5p) and 7 with decreased expression in inflammatory breast cancer (miR-15a, miR-24, miR-29a, miR-30b, miR-320, miR-342-5p, and miR-342-3p). ${ }^{64}$ In the other study, the expression of 804 miRNAs in 12 inflammatory breast cancer and 31 noninflammatory breast cancer human samples was examined, and the differentially expressed miRNAs were then validated in 65 inflammatory breast cancer and 95 noninflammatory breast cancer human samples. Thirteen miRNAs were validated to be differentially expressed between inflammatory breast cancer and noninflammatory breast cancer, including 12 with increased expression in inflammatory breast cancer (miR-7, miR-21, miR-301b, miR-324-5p, miR-421, miR-486, miR-503, miR-720, miR-1234, miR-1274a, miR-1308, and miR-1825) and 1 with decreased expression in inflammatory breast cancer (miR-1303). In addition, a 5-miRNA signature composed of miR-421, miR-486, MiR-503, miR-720, and miR-1303 was predictive for inflammatory breast cancer. ${ }^{65}$ Apparently, the two published miRNA profiles in inflammatory breast cancer and our study results do not overlap. Small sample size may partly contribute to the lack of common profile. In addition, the selection of the noninflammatory breast cancer group varied among the three studies.
The second published study selected a group of noninflammatory breast cancer cases that were significantly different from the inflammatory breast cancer ones in age, tumor histologic grade, stage, estrogen receptor status, progesterone receptor status, HER2 status, and distant metastasis, in contrast to the other two studies where the inflammatory breast cancer group and noninflammatory breast cancer group were only significantly different in tumor stage. Whereas the first published study included a considerable proportion of early-stage patients in the noninflammatory breast cancer group $(42 \%$ of the noninflammatory breast cancer cases were stage I), our study included only clinically and/or pathologically $\mathrm{T} 4$, or tumor $\geq 5 \mathrm{~cm}$, or T2 (tumor $\geq 3 \mathrm{~cm}$ ) N2 patients in the noninflammatory breast cancer group, thus eliminating any early-stage patients. In our study, the inflammatory breast cancer and noninflammatory breast cancer groups were only different in pathologic stage but not clinical stage, most likely because of the fact that inflammatory breast cancer patients were not clinically restaged after neoadjuvant chemotherapy based on residual tumor size (T stage) as noninflammatory breast cancer patients, and hence the inflammatory breast cancer patients in our cohort appeared to have a higher 


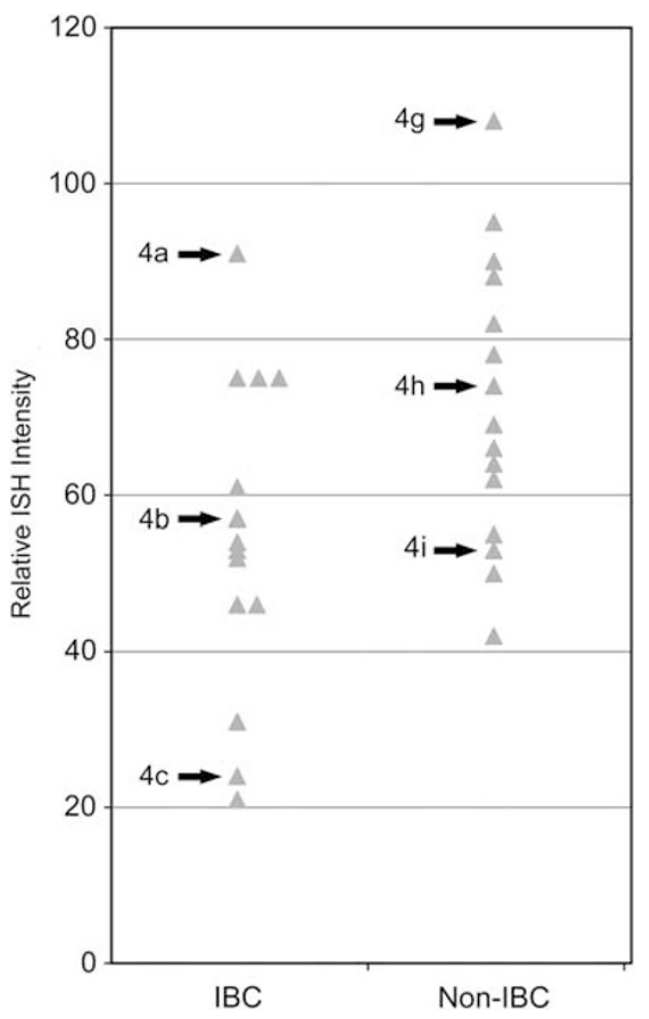

Figure 5 The miR-205 in situ hybridization results showing relative intensities. Each triangle represents one tumor. Arrows on the left sides of the triangles mark the tumors shown in Figure 4. IBC, inflammatory breast cancer.

pathologic stage. Overall, our study results represented a miRNA profile of advanced breast cancers, and the differential expression of miRNA was obtained between inflammatory breast cancer and more advanced noninflammatory breast cancer in comparison with the other two studies. Nevertheless, the significant miRNAs from the three studies may serve as candidate markers for inflammatory breast cancer and can be further investigated.

Human miR-205 is located at the junction of the second intron and third exon of LOC642587 locus in chromosome $1{ }^{66}$ It has been found that miR-205 is a highly conserved miRNA with homologs in different species. Recent studies on the functions of miR-205 have implicated its role in normal development and cancer. In mouse mammary gland development, miR-205 is strongly expressed in the basal epithelial cells, including both myoepithelial cells and basal stem cells, until the mature virgin stage, and has increased expression in both the luminal and basal epithelium during pregnancy and in late involution. ${ }^{67}$ In addition, high expression of miR-205 has been observed in stem cell-enriched populations of normal mouse mammary epithelial cells isolated by FACS purification. ${ }^{68}$ Thus, miR-205 may play a role in mammary epithelial stem cell proliferation and differentiation. Its functions in cancer appear to be tissue type specific. MiR-205 expression level is reportedly upregulated in human
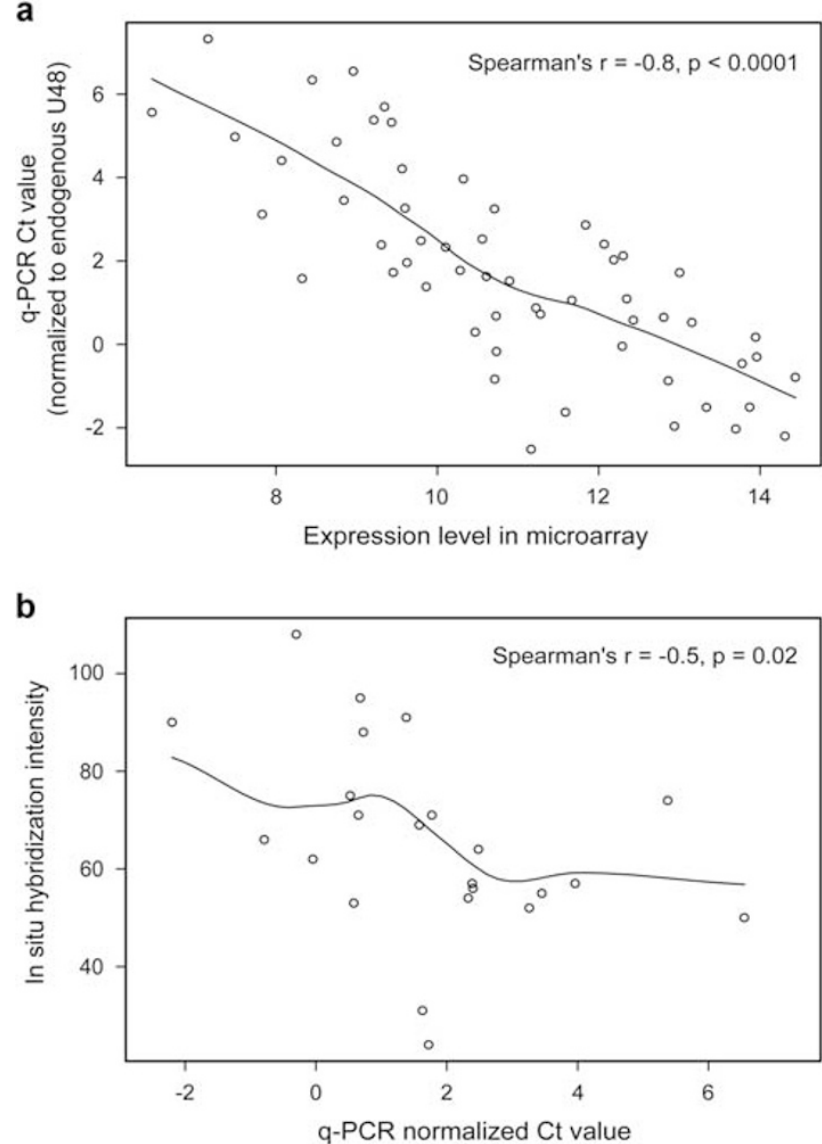

Figure 6 Correlation between different miR-205 analyses. (a) Correlation between microarray analysis and quantitative PCR. (b) Correlation between quantitative PCR and in situ hybridization. Ct, cycle threshold.

samples of lung cancer, ${ }^{69}$ bladder cancer, ${ }^{70}$ and endometrioid adenocarcinoma, ${ }^{71}$ and downregulated in breast cancer, ${ }^{72-74}$ prostate cancer, ${ }^{75}$ and melanoma. ${ }^{76}$ It has been reported that in a cohort of early breast cancer patients, decreased miR-205 is associated with worse disease-free interval and overall survival. ${ }^{77}$ Similarly, in our cohort of advanced breast cancer patients, lower miR-205 expression is also associated with worse survival.

In cultured breast cancer cell lines, miR-205 is shown to suppress proliferation, clonogenic survival, anchorage-independent growth, and invasiveness, indicating its role in tumor cell growth, invasion, and metastasis. ${ }^{72}$ Furthermore, miR-205 has been found to negatively regulate epithelial-mesenchymal transition, an essential early step in tumor metastasis. In cell culture models, miR-205, along with the miR-200 family, suppresses the expression of ZEB1 and ZEB2, repressors of E-cadherin transcription that have been implicated in epithelialmesenchymal transition. ${ }^{60}$ Downregulation of miR-205 is also seen in epithelial-mesenchymal transition induced by mammosphere culture of breast cancer cell line MCF-7.78 Interestingly, 
IBC
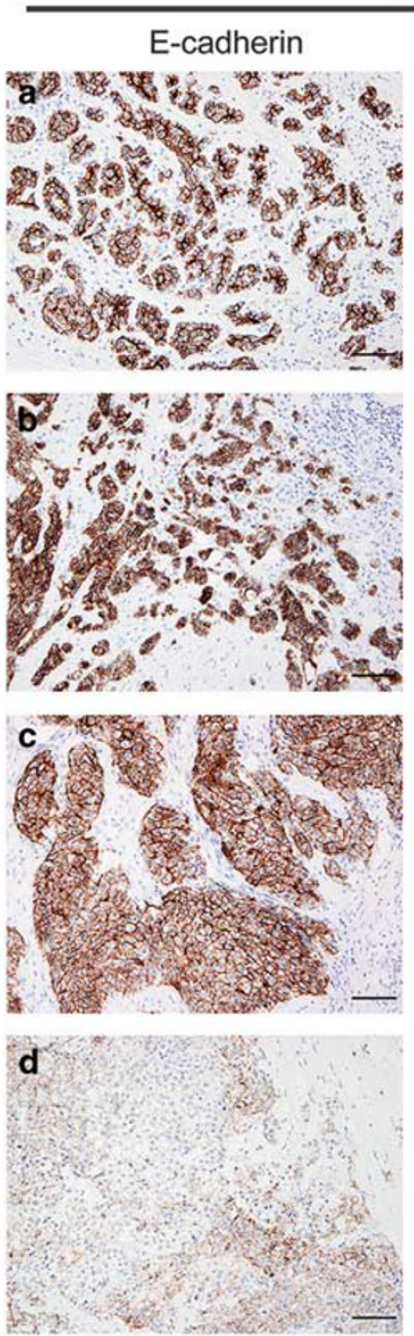

Vimentin
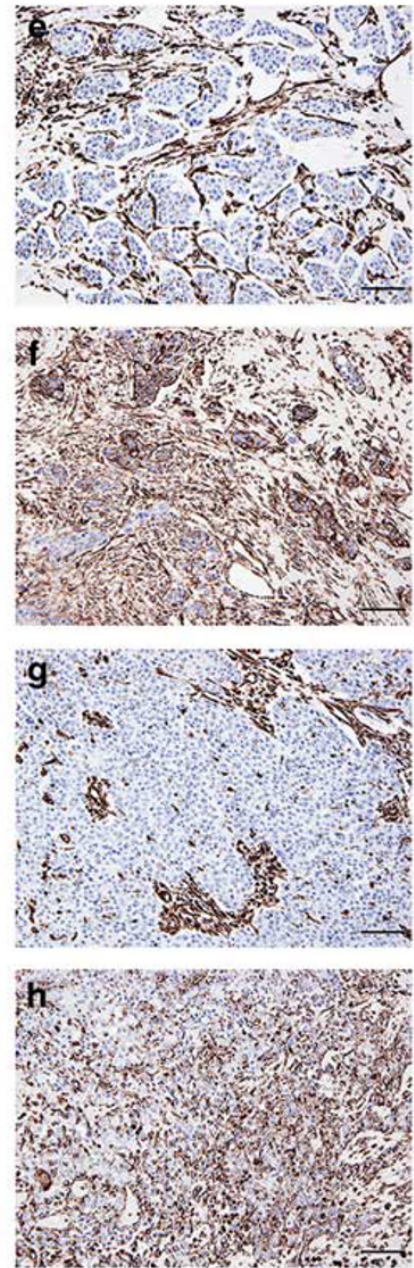

IBC
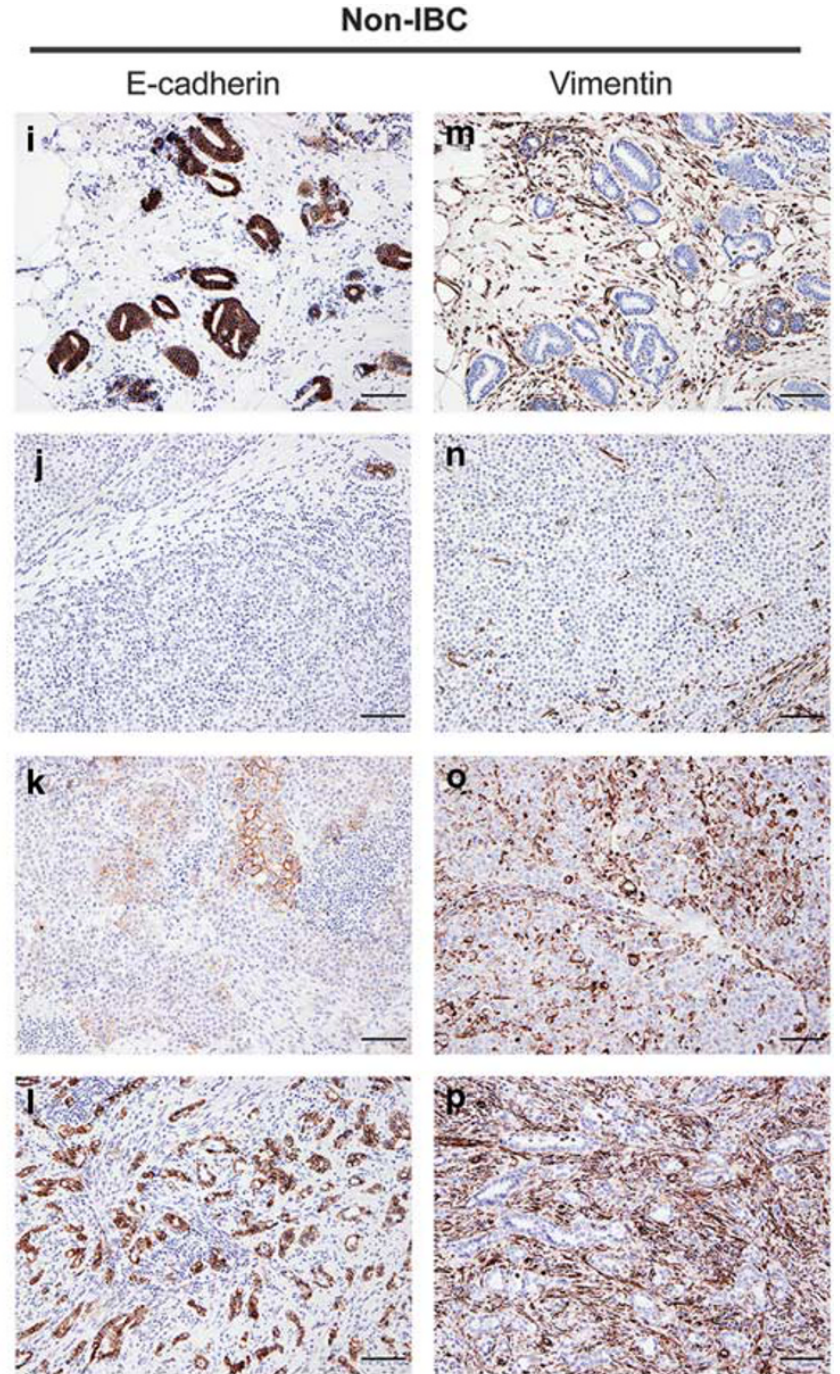

Non-IBC

\begin{tabular}{|c|c|c|c|c|c|}
\hline ISH & E-cadherin & Vimentin & E-cadherin & Vimentin & ISH \\
\hline 91 & Positive & Negative & Positive & Negative & 108 \\
\hline 75 & Positive & Positive & Negative & Negative & 78 \\
\hline 31 & Positive & Negative & Marked decrease/patchy & Positive & 53 \\
\hline 24 & Marked decrease/patchy & Positive & Positive & Negative & 42 \\
\hline
\end{tabular}

Figure 7 Immunohistochemical staining for E-cadherin and vimentin. The inflammatory breast cancer (IBC) cases are shown on the left (a-d, E-cadherin; $\mathbf{e}-\mathbf{h}$, vimentin in corresponding cases) and the noninflammatory breast cancer cases on the right (i-l, E-cadherin; $\mathbf{m}-\mathbf{p}$, vimentin in corresponding cases). The table summarizes the results in the same order as shown in the photomicrographs, with the relative miR-205 in situ hybridization intensities on the left side for the IBC tumors and on the right side for the non-IBC tumors.

expression of miR-205 is downregulated in breast cancer cell lines that belong to claudin-low subtype, which is known to be associated with high epithelial-mesenchymal transition, ${ }^{79}$ as well as in triple-negative breast cancer human samples. ${ }^{74,80}$ Of note, the commonly used triple-negative inflammatory breast cancer cell line SUM149, unlike the claudin-low subtype of breast cancer cell lines, does not contain a detectable mesenchymal subpopulation ${ }^{81,82}$ and demonstrates a much higher expression level of miR-205 than the triple-negative breast cancer cell lines with a mesenchymal phenotype. ${ }^{79}$ Consistent with its potential role in tumor metastasis demonstrated in vitro, a recent miRNA expression profiling study of human metastatic cancers demonstrated miR-205 downregulation in metastatic breast cancer in lymph nodes compared with primary breast cancers, but not 
in metastatic cancers from the colon, bladder, or lung. ${ }^{26}$ Identified direct targets of miR-205 in breast cancer include VEGF-A, a key regulator of angiogenesis and tumor metastasis, ${ }^{72}$ E2F1, LAMC $1,{ }^{79}$ and HER3. ${ }^{72,73}$ Heterodimerization of HER2-HER3 leads to the activation of PI3K/Akt survival pathway, critical for HER2-mediated tumorigenesis. It was found that enforced expression of miR-205 in cultured breast cancer cells increases the responsiveness to EGFR inhibitor Gefitinib and EGFR/HER2 inhibitor Lapatinib. ${ }^{73}$ It is conceivable that miR-205 may affect tumor growth and metastasis by simultaneously targeting multiple genes. Additional targets of miR-205 identified in other tissue types have not been validated in breast cancer. ${ }^{83-86}$ Likely, miR-205 plays a role in specific pathways in tumorigenesis and tumor progression in a cell type-specific manner.

It has been reported that miR-205 is restricted to myoepithelial cells in normal epithelial structures, ${ }^{58,59}$ and its expression is reduced or completely eliminated in matching tumor specimens. ${ }^{58}$ However, our in situ hybridization analysis showed expression in luminal cells in normal ducts and lobules in some cases. This observation suggests that miR-205 expression may be regulated by physiologic changes in the mammary tissue, similar to the shift of expression from the basal epithelium to both the basal and luminal epithelium in mouse mammary gland development. ${ }^{67}$ We did observe a stronger expression in the basal cell layer in the majority of cases, and it is possible that the less frequent expression in luminal cells was not observed in previous studies because of the use of tissue microarrays.

It has been reported that in early invasive breast cancer, miR-205 expression detected by in situ hybridization is positively related to ductal morphology, presumably because miR-205 regulates E-cadherin expression, and E-cadherin is known to be lost in lobular carcinoma. ${ }^{59}$ However, in the cohort of advanced breast cancers used for the current study, the two invasive lobular carcinomas (noninflammatory breast cancer) appeared to have intermediate staining of miR-205 compared with other ductal carcinomas, suggesting that the regulation of E-cadherin many have different mechanisms. Furthermore, it has been shown that E-cadherin is expressed at higher levels in inflammatory breast cancer compared with noninflammatory breast cancer, regardless of ductal vs lobular phenotype. ${ }^{62,63}$ However, from the role of E-cadherin in epithelial-mesenchymal transition, it is expected that inflammatory breast cancer would have decreased expression of E-cadherin, although it is possible that its expression is temporally controlled. Consistent with the latter hypothesis, one study showed that the xenografts of MDA-IBC-3 cells (derived from inflammatory breast cancer patients) had faster growth rate when coinjected with human bone marrow-derived mesenchymal stem cells, and had decreased expression of E-cadherin. ${ }^{87}$ The mesenchymal stem cells used in that study were known to promote epithelial-mesenchymal transition and breast cancer metastasis. Although our results on E-cadherin and vimentin expression raise the possibility that a subset of tumors with low miR-205, including but not restricted to inflammatory breast cancer, may have decreased E-cadherin expression and expression of vimentin even though they have ductal differentiation, the data are very limited. Additional large studies are necessary to establish the correlation between E-cadherin, vimentin, and miR-205 expression.

In summary, by microarray analysis and quantitative RT-PCR performed on fresh frozen tissue and in situ hybridization on formalin-fixed, paraffin-embedded samples, our study showed that miR-205 was downregulated in advanced breast cancer, especially in inflammatory breast cancer. Recent studies have shown that in mouse models, delivery of miR-205 through nanoliposomes can sensitize breast tumors to radiation, ${ }^{88}$ and induction of miR-205 expression by an antioxidant negatively modulates epithelial-mesenchymal transition and inhibits triple-negative breast cancer metastasis. ${ }^{89}$ Thus, miR-205 may be a potential therapeutic target for advanced breast cancer including inflammatory breast cancer.

\section{Acknowledgments}

We thank Herminia Patino for her excellent clerical assistance and Kim-Anh $\mathrm{Vu}$ and Joseph Munch for their assistance with the manuscript. This project is supported in part by the MDACC institutional start-up funds to LH, Morgan Welch Inflammatory Breast Cancer Research Program, and State of Texas Rare and Aggressive Breast Cancer Research Program Grant.

\section{Disclosure/conflict of interest}

The authors declare no conflict of interest.

\section{References}

1 Hance KW, Anderson WF, Devesa SS et al. Trends in inflammatory breast carcinoma incidence and survival: the surveillance, epidemiology, and end results program at the National Cancer Institute. J Natl Cancer Inst 2005;97:966-975.

2 Anderson WF, Schairer C, Chen BE et al. Epidemiology of inflammatory breast cancer (IBC). Breast Dis 2005-2006;22:9-23.

3 Dawood S, Cristofanilli M. Inflammatory breast cancer: what progress have we made? Oncology (Williston Park) 2011;25:264-273. 
4 Masuda H, Brewer TM, Liu DD et al. Long-term treatment efficacy in primary inflammatory breast cancer by hormonal receptor- and HER2-defined subtypes. Ann Oncol 2014;25:384-391.

5 Bertucci F, Finetti P, Rougemont J et al. Gene expression profiling for molecular characterization of inflammatory breast cancer and prediction of response to chemotherapy. Cancer Res 2004;64:8558-8565.

6 Bertucci F, Finetti P, Rougemont J et al. Gene expression profiling identifies molecular subtypes of inflammatory breast cancer. Cancer Res 2005;65:2170-2178.

7 Van Laere S, Van der Auwera I, Van den Eynden GG et al. Distinct molecular signature of inflammatory breast cancer by cDNA microarray analysis. Breast Cancer Res Treat 2005;93:237-246.

8 Van Laere SJ, Van den Eynden GG, Van der Auwera I et al. Identification of cell-of-origin breast tumor subtypes in inflammatory breast cancer by gene expression profiling. Breast Cancer Res Treat 2006;95: 243-255.

9 Van Laere S, Van der Auwera I, Van den Eynden G et al. Distinct molecular phenotype of inflammatory breast cancer compared to non-inflammatory breast cancer using Affymetrix-based genome-wide gene-expression analysis. $\mathrm{Br} \mathrm{J}$ Cancer 2007;97: 1165-1174.

10 Bieche I, Lerebours F, Tozlu S et al. Molecular profiling of inflammatory breast cancer: identification of a poorprognosis gene expression signature. Clin Cancer Res 2004;10:6789-6795.

11 Dressman HK, Hans C, Bild A et al. Gene expression profiles of multiple breast cancer phenotypes and response to neoadjuvant chemotherapy. Clin Cancer Res 2006;12:819-826.

12 Nguyen DM, Sam K, Tsimelzon A et al. Molecular heterogeneity of inflammatory breast cancer: a hyperproliferative phenotype. Clin Cancer Res 2006;12: 5047-5054.

13 Boersma BJ, Reimers M, Yi M et al. A stromal gene signature associated with inflammatory breast cancer. Int J Cancer 2008;122:1324-1332.

14 Iwamoto T, Bianchini G, Qi Y et al. Different gene expressions are associated with the different molecular subtypes of inflammatory breast cancer. Breast Cancer Res Treat 2011;125:785-795.

15 Bertucci F, Finetti P, Birnbaum D et al. Gene expression profiling of inflammatory breast cancer. Cancer 2010;116:2783-2793.

16 Van Laere SJ, Ueno NT, Finetti P et al. Uncovering the molecular secrets of inflammatory breast cancer biology: an integrated analysis of three distinct Affymetrix gene expression datasets. Clin Cancer Res 2013;19: 4685-4696.

17 Zeng Y, Yi R, Cullen BR. MicroRNAs and small interfering RNAs can inhibit mRNA expression by similar mechanisms. Proc Natl Acad Sci USA 2003;100:9779-9784.

18 Iorio MV, Ferracin M, Liu CG et al. MicroRNA gene expression deregulation in human breast cancer. Cancer Res 2005;65:7065-7070.

19 Christodoulatos GS, Dalamaga M. Micro-RNAs as clinical biomarkers and therapeutic targets in breast cancer: Quo vadis? World J Clin Oncol 2014;5: 71-81.

20 Valastyan S. Roles of microRNAs and other non-coding RNAs in breast cancer metastasis. J Mammary Gland Biol Neoplasia 2012;17:23-32.
21 Wang L, Wang J. MicroRNA-mediated breast cancer metastasis: from primary site to distant organs. Oncogene 2012;31:2499-2511.

22 Ferracin M, Querzoli P, Calin GA et al. MicroRNAs: toward the clinic for breast cancer patients. Semin Oncol 2011;38:764-775.

23 Castañeda CA, Agullo-Ortuño MT, Fresno Vara JA et al. Implication of miRNA in the diagnosis and treatment of breast cancer. Expert Rev Anticancer Ther 2011;11: 1265-1275.

24 Lowery AJ, Miller N, Devaney A et al. MicroRNA signatures predict oestrogen receptor, progesterone receptor and HER2/neu receptor status in breast cancer. Breast Cancer Res 2009;11:R27.

25 Andorfer CA, Necela BM, Thompson EA et al. MicroRNA signatures: clinical biomarkers for the diagnosis and treatment of breast cancer. Trends Mol Med 2011;17:313-319.

26 Baffa R, Fassan M, Volinia S et al. MicroRNA expression profiling of human metastatic cancers identifies cancer gene targets. J Pathol 2009;219: 214-221.

27 Blenkiron C, Goldstein LD, Thorne NP et al. MicroRNA expression profiling of human breast cancer identified new markers of tumor subtype. Genome Biol 2007;8: R214.

28 Lewis BP, Burge CB, Bartel DP. Conserved seed pairing, of-ten flanked by adenosines, indicates that thousands of human genes are microRNA targets. Cell 2005;120: 15-20.

29 Liu CG, Calin GA, Meloon B et al. An oligonucleotide microchip for genome-wide miRNA profiling in human and mouse tissues. Proc Natl Acad Sci USA 2004;101: 9740-9744.

30 Liu CG, Calin GA, Volinia S et al. MicroRNA expression profiling using microarrays. Nat Protoc 2008;3: 563-578.

31 Hammond ME, Hayes DF, Dowsett $M$ et al. American Society of Clinical Oncology/College of American Pathologists guideline recommendations for immunohistochemical testing of estrogen and progesterone receptors in breast cancer. Arch Pathol Lab Med 2010;134:907-922.

32 Wolff AC, Hammond ME, Schwartz JN et al. American Society of Clinical Oncology/College of American Pathologists guideline recommendations for human epidermal growth factor receptor 2 testing in breast cancer. Arch Pathol Lab Med 2007;131:18-43.

33 Jin L, Wessely O, Marcusson EG et al. Prooncogenic factors miR-23b and miR-27b are regulated by Her2/Neu, EGF, and TNF- $\alpha$ in breast cancer. Cancer Res 2013;73:2884-2896.

34 Ell B, Qiu Q, Wei Y et al. The microRNA-23b/27b/24 cluster promotes breast cancer lung metastasis by targeting metastasis-suppressive gene prosaposin. J Biol Chem 2014;289:21888-21895.

35 Krell J, Frampton AE, Jacob J et al. miRNAs in breast cancer: ready for real time? Pharmacogenomics 2012;13:709-719.

36 Zhang ZJ, Ma SL. miRNAs in breast cancer tumorigenesis. Oncol Rep 2012;27:903-910.

37 Iorio MV, Casalini P, Piovan C et al. Breast cancer and microRNAs: therapeutic impact. Breast 2011;20: S63-S70.

38 Sempere LF. Integrating contextual miRNA and protein signatures for diagnostic and treatment decisions in cancer. Expert Rev Mol Diagn 2011;11:813-827. 
39 Götte M. MicroRNAs in breast cancer pathogenesis. Minerva Ginecol 2010;62:559-571.

40 Corcoran C, Friel AM, Duffy MJ et al. Intracellular and extracellular microRNAs in breast cancer. Clin Chem 2011;57:18-32.

41 Heneghan HM, Miller N, Kerin MJ. MiRNAs as biomarkers and therapeutic targets in cancer. Curr Opin Pharmacol 2010;10:543-550.

42 Le Quesne J, Caldas C. Micro-RNAs and breast cancer. Mol Oncol 2010;4:230-241.

43 Khoshnaw SM, Green AR, Powe DG et al. MicroRNA involvement in the pathogenesis and management of breast cancer. J Clin Pathol 2009;62:422-428.

44 O'Day E, Lal A. MicroRNAs and their target gene networks in breast cancer. Breast Cancer Res 2010;12: 201.

45 Serpico D, Molino L, Di Cosimo S. microRNAs in breast cancer development and treatment. Cancer Treat Rev 2014;40:595-604.

46 Mulrane L, Klinger R, McGee SF et al. microRNAs: a new class of breast cancer biomarkers. Expert Rev Mol Diagn 2014;14:347-363.

$47 \mathrm{Li} \mathrm{QQ}$, Chen ZQ, Cao XX et al. Involvement of NF- $\mathrm{kB} / \mathrm{miR}-448$ regulatory feedback loop in chemotherapy-induced epithelial-mesenchymal transition of breast cancer cells. Cell Death Differ 2011;18: $16-25$.

48 Navon R, Wang H, Steinfeld I et al. Novel rank-based statistical methods reveal microRNAs with differential expression in multiple cancer types. PLoS One 2009;4: e8003.

49 Jin C, Rajabi H, Kufe D. miR-1226 targets expression of the mucin 1 oncoprotein and induces cell death. Int J Oncol 2010;37:61-69.

50 Shi M, Liu D, Duan H et al. Metastasis-related miRNAs, active players in breast cancer invasion, and metastasis. Cancer Metastasis Rev 2010;29:785-799.

51 Singh R, Mo YY. Role of microRNAs in breast cancer. Cancer Biol Ther 2013;14:201-212.

52 Piao HL, Ma L. Non-coding RNAs as regulators of mammary development and breast cancer. J Mammary Gland Biol Neoplasia. 2012;17:33-42.

53 Guttilla IK, Adams BD, White BA. ER $\alpha$, microRNAs, and the epithelial-mesenchymal transition in breast cancer. Trends Endocrinol Metab 2012;23: 73-82.

54 Gyparaki MT, Basdra EK, Papavassiliou AG. MicroRNAs as regulatory elements in triple negative breast cancer. Cancer Lett 2014;354:1-4.

55 Stecklein SR, Jensen RA, Pal A. Genetic and epigenetic signatures of breast cancer subtypes. Front Biosci (Elite Ed) 2012;4:934-949.

56 Zhang W, Liu J, Wang G. The role of microRNAs in human breast cancer progression. Tumour Biol 2014;35:6235-6244.

57 Majumder S, Jacob ST. Emerging role of microRNAs in drug-resistant breast cancer. Gene Expr 2011;15: 141-151.

58 Sempere LF, Christensen M, Silahtaroglu A et al. Altered microRNA expression confined to specific epithelial cell subpopulations in breast cancer. Cancer Res. 2007;67:11612-11620.

59 Quesne JL, Jones J, Warren J et al. Biological and prognostic associations of miR-205 and let-7b in breast cancer revealed by in situ hybridization analysis of micro-RNA expression in arrays of archival tumour tissue. J Pathol 2012;227:306-314.
60 Blenkiron C, Goldstein LD, Thorne NP et al. MicroRNA expression profiling of human breast cancer identifies new markers of tumor subtype. Genome Biol 2007;8: R214.

61 Lee JY, Park MK, Park JH et al. Loss of the polycomb protein Mel-18 enhances the epithelial-mesenchymal transition by ZEB1 and ZEB2 expression through the downregulation of miR-205 in breast cancer. Oncogene 2014;33:1325-1335.

62 Kleer CG, van Golen KL, Braun T et al. Persistent E-cadherin expression in inflammatory breast cancer. Mod Pathol 2001;14:458-464.

63 Levine PH, Portera CC, Hoffman HJ et al. Evaluation of lymphangiogenic factors, vascular endothelial growth factor D and E-cadherin in distinguishing inflammatory from locally advanced breast cancer. Clin Breast Cancer 2012;12:232-239.

64 Van der Auwera I, Limame $\mathrm{R}$, van Dam $\mathrm{P}$ et al. Integrated miRNA and mRNA expression profiling of the inflammatory breast cancer subtype. Br J Cancer 2010;103:532-541.

65 Lerebours F, Cizeron-Clairac G, Susini A et al. miRNA expression profiling of inflammatory breast cancer identifies a 5-miRNA signature predictive of breast tumor aggressiveness. Int J Cancer 2013;133: 1614-1623.

$66 \mathrm{Wu} \mathrm{H}$, Mo YY. Targeting miR-205 in breast cancer. Expert Opin Ther Targets 2009;13:1439-1448.

67 Avril-Sassen S, Goldstein LD, Stingl J et al. Characterisation of microRNA expression in post-natal mouse mammary gland development. BMC Genomics 2009;10:548.

68 Greene SB, Gunaratne PH, Hammond SM et al. A putative role for microRNA-205 in mammary epithelial cell progenitors. J Cell Sci 2010;123:606-618.

69 Markou A, Tsaroucha EG, Kaklamanis L et al. Prognostic value of mature microRNA-21 and microRNA-205 overexpression in non-small cell lung cancer by quantitative real-time RT-PCR. Clin Chem 2008;54:1696-1704.

70 Gottardo F, Liu CG, Ferracin $\mathrm{M}$ et al. Micro-RNA profiling in kidney and bladder cancers. Urol Oncol 2007;25:387-392.

$71 \mathrm{Wu} \mathrm{W}$, Lin Z, Zhuang Z et al. Expression profile of mammalian microRNAs in endometrioid adenocarcinoma. Eur J Cancer Prev 2009;18:50-55.

$72 \mathrm{Wu} \mathrm{H}$, Zhu S, Mo YY. Suppression of cell growth and invasion by miR-205 in breast cancer. Cell Res 2009;19: 439-448.

73 Iorio MV, Casalini P, Piovan C et al. microRNA-205 regulates HER3 in human breast cancer. Cancer Res 2009;69:2195-2200.

74 Radojicic J, Zaravinos A, Vrekoussis T et al. MicroRNA expression analysis in triple-negative (ER, PR and Her2/neu) breast cancer. Cell Cycle 2011;10:507-517.

75 Schaefer A, Jung M, Mollenkopf HJ et al. Diagnostic and prognostic implications of microRNA profiling in prostate carcinoma. Int J Cancer 2010;126: 1166-1176.

76 Philippidou D, Schmitt M, Moser D et al. Signatures of microRNAs and selected microRNA target genes in human melanoma. Cancer Res 2010;70: 4163-4173.

77 Markou A, Yousef GM, Stathopoulos E et al. Prognostic significance of metastasis-related microRNAs in early breast cancer patients with a long follow-up. Clin Chem 2014;60:197-205. 
78 Guttilla IK, Phoenix KN, Hong X et al. Prolonged mammosphere culture of MCF-7 cells induces an EMT and repression of the estrogen receptor by microRNAs. Breast Cancer Res Treat 2012;132:75-85.

79 Piovan C, Palmieri D, Di Leva G et al. Oncosuppressive role of p53-induced miR-205 in triple negative breast cancer. Mol Oncol 2012;6:458-472.

80 Savad S, Mehdipour P, Miryounesi M et al. Expression analysis of miR-21, miR-205, and miR-342 in breast cancer in Iran. Asian Pac J Cancer Prev 2012;13: 873-877.

81 Prat A, Perou CM. Deconstructing the molecular portraits of breast cancer. Mol Oncol 2011;5:5-23.

82 Ma L, Young J, Prabhala H et al. miR-9, a MYC/MYCNactivated microRNA, regulates E-cadherin and cancer metastasis. Nat Cell Biol 2010;12:247-256.

83 Majid S, Dar AA, Saini S et al. MicroRNA-205-directed transcriptional activation of tumor suppressor genes in prostate cancer. Cancer 2010;116:5637-5649.

84 Gandellini P, Folini M, Longoni N et al. miR-205 Exerts tumor-suppressive functions in human prostate through down-regulation of protein kinase Cepsilon. Cancer Res 2009;69:2287-2295.

$85 \mathrm{Yu}$ J, Ryan DG, Getsios S et al. MicroRNA-184 antagonizes microRNA-205 to maintain SHIP2 levels in epithelia. Proc Natl Acad Sci USA 2008;105: 19300-19305.

86 Majid S, Saini S, Dar AA et al. MicroRNA-205 inhibits Src-mediated oncogenic pathways in renal cancer. Cancer Res 2011;71:2611.

87 lopp AH, Lacerda L, Gupta A et al. Mesenchymal stem cells promote mammosphere formation and decrease E-cadherin in normal and malignant breast cells. PLoS One 2010;5:e12180.

88 Zhang P, Wang L, Rodriguez-Aguayo C et al. miR-205 acts as a tumour radiosensitizer by targeting ZEB1 and Ubc13. Nat Commun 2014;5:5671.

89 Su CM, Lee WH, Wu AT et al. Pterostilbene inhibits triple-negative breast cancer metastasis via inducing microRNA-205 expression and negatively modulates epithelial-to-mesenchymal transition. J Nutr Biochem 2015;26:675-685. 